\title{
Tapetes Musicais Inteligentes: Computação Ubiqua para apoiar a Educação Musical
}

\author{
Title: Inteligent Musical Rugs : Ubiquitous Computing to Support Musical Education \\ Thiago Marcondes Santos \\ PPGI-Programa de pós Graduação em \\ Informática - Universidade Federal \\ do Estado do Rio de Janeiro \\ (UNIRIO) \\ thiagomarcondes@hotmail.com \\ Mariano Pimentel \\ PPGI-Programa de pós Graduação em \\ Informática - Universidade Federal \\ do Estado do Rio de Janeiro \\ (UNIRIO) \\ pimentel@unriotec.br \\ Denise Del Re Filippo \\ Escola Superior de Desenho Industri- \\ al (Esdi) - Universidade do Estado do \\ Rio de Janeiro (Uerj) \\ dfilippo@esdi.uerj.br
}

\begin{abstract}
Resumo Aprender um instrumento musical está associado a horas de prática para aperfeiçoamento técnico e evolução musical do estudante, deixando fora desse processo muitos interessados que não podem se dedicar tanto. A dedicação exigida se deve às características físicas de cada instrumento e sua maneira particular de gerar o som. Com as novas tecnologias advindas com a computação ubíqua, outras formas de se gerar som têm possibilitado outras abordagens para a criação e educação musical. Este artigo descreve uma investigação do uso da computação ubíqua no contexto de sala de aula do ensino fundamental com intuito de promover a aprendizagem e a vivência de conceitos musicais. Num estudo de caso exploratório, realizado em 2 escolas públicas municipais do Rio de Janeiro com 2 turmas de $7^{\circ}$ ano do ensino fundamental, o ambiente escolar foi transformado em um laboratório sonoro, cujos sons foram ativados a partir de contatos corporais já conhecidos dos estudantes, como o bater de palmas. Desta forma, a sala de aula se apresenta como instrumento musical coletivo, diminuindo as barreiras técnicas necessárias à execução musical.
\end{abstract}

Palavras-Chave: Internet das Coisas, Computação Ubíqua, Objetos Inteligentes, Educação, Música

\begin{abstract}
Learning a musical instrument is associated with hours of practice for the technical improvement and musical evolution on the part of the student, leaving out many of those who have interest, but cannot dedicate themselves so thoroughly to the process. This is due to the physical characteristics of each instrument and their particular way of generating sound. With new computer technologies, such as ubiquitous computing, other ways of generating sound allow for new approaches in musical creation and education. This article describes an investigation of the use of ubiquitous computing in the context of an elementary school classroom with the intent of promoting the learning and experiencing of musical concepts. In an exploratory case study, done in 2 municipal public schools in Rio de Janeiro with 2 elementary school 7th grade classes, the school environment was transformed into a sound laboratory, whose sounds were activated using body movements that the students were already familiar with, such as clapping hands. Thus, the classroom is presented as a collective musical instrument, lessening the technical barriers that are necessary to musical execution.
\end{abstract}

Keywords: Internet of Things, Ubiquitous Computing, Intelligent Objects, Education, Music. 


\section{Introdução}

Na pesquisa aqui relatada, desenvolvemos os Tapetes Musicais Inteligentes para apoiar o professor de música em seu trabalho de mediador entre o estudante e o conhecimento musical. Este artefato foi projetado para diminuir as barreiras técnicas na produção sonora em comparação com as demandas exigidas para se tocar um instrumento tradicional. Os estudantes, descalços sobre os tapetes conectados a um computador, ao se tocarem, fecham o circuito elétrico com seus próprios corpos, o que dispara um som previamente definido pelo professor para cada par de tapetes: cuíca, piano, acordes, chuva, latido, qualquer som digitalizado.

A motivação deste trabalho reside na lei 11.769/08 [14] que prevê a volta do ensino de música nas escolas do Brasil. Com esta lei aumentam significativamente a quantidade de estudantes que agora necessitam de ensino musical nas escolas do país. Esta motivação é abordada na seção 2 .

O problema de pesquisa deste estudo reside no fato de ainda haver uma predominância de abordagens comportamentalistas no ensino de música, onde a aquisição de habilidades técnicas no manuseio de instrumentos musicais tradicionais ainda são privilegiadas, o que implica em um longo e árduo caminho a ser seguido pelos estudantes que desejam aprender música nas escolas. Neste contexto pesquisamos alternativas que facilitem o aprendizado musical e que incentivem o sócio-interacionismo, que se apresenta como alternativa pedagógica ao ensino comportamentalista nas escolas. $\mathrm{O}$ artefato foi projetado com base em algumas premissas, dentre elas: facilitar a produção de som para que mesmo crianças não iniciadas possam rapidamente participar do discurso musical; exigir o uso de movimentos corporais na produção sonora, usando assim o corpo como um intermediador entre os sons e o pensamento; e promover a colaboração entre os estudantes, colocando em evidência a importância das interações sociais e da mediação cultural no desenvolvimento intelectual das crianças interagindo com o professor e seus colegas. Essas premissas foram obtidas a partir de teóricos sobre educação e música, conforme apresentado na Seção 2.

Para guiar o desenvolvimento do artefato, baseado em computação ubíqua (Seção 3), seguimos o método Design Science Research, explicado na Seção 4. Como resultado, além dos Tapetes Musicais Inteligentes, projetamos também algumas atividades educacionais para o uso do artefato, conforme apresentado na Seção 5 .

$\mathrm{O}$ presente artigo deriva de uma dissertação de mes- trado [24] e também é uma versão estendida do artigo premiado como melhor artigo do WIE 2015 [23].

Para avaliar o artefato, as atividades educacionais e as conjecturas teóricas que fundamentaram o projeto do artefato, foi realizado um estudo de caso em duas escolas onde foram realizadas oficinas pedagógicas com o uso dos Tapetes Musicais Inteligentes em aulas de música. Os resultados produzidos neste estudo estão analisados na Seção 6. A conclusão desta pesquisa e os trabalhos futuros são apresentados na Seção 7.

\section{Ensino de música}

A lei 11.769/08 [14] estabeleceu a volta do ensino obrigatório de música nas escolas brasileiras. Esta lei torna o aprendizado musical não um tópico restrito a uma parte da população, mas sim um elemento de formação de todo cidadão. No entanto, a produção musical pelos estudantes, quando dependente de questões técnicas de determinados instrumentos, se torna um processo penoso e desgastante, principalmente para os estudantes nos anos iniciais de formação.

Pensadores como Emile Dalcroze e Carl Orff, já na $1^{\mathrm{a}}$ metade do século XX, apontavam novas direções para o ensino musical que até então era baseado num paradigma de execução de um instrumento orientado ao repertório clássico vigente e de ênfase ao virtuosismo instrumental. Tais procedimentos pedagógicos afastavam os estudantes da música e os direcionavam para práticas técnicas dos instrumentos [6]. Dalcroze e Orff também defendiam o uso do corpo e do movimento através de gestos como intermediadores do processo de conhecimento musical dando suporte ao entendimento e assimilação do discurso musical [6][10].

Educadores como Orff buscavam facilitar a produção do som utilizando instrumentos como o metalofone e o xilofone, que possibilitam a geração do som sem muito esforço técnico. Adicionalmente, o xilofone, por ser construído com barras que podem ser retiradas, possibilita ser configurado para que sejam evitados determinados erros por parte do estudante num dado exercício: por exemplo, é possível retirar barras deixando apenas o subconjunto específico de notas com as quais ele vai trabalhar em sala de aula. Evitam-se, assim, problemas com questões de execução técnica como notas excedentes que podem induzir o estudante ao erro. Orff também defende que todo material que a criança já tem em seu acervo de conhecimento deve ser usado a seu favor: as brincadeiras de palmas e cantos das crianças, além da própria métrica e ritmo da linguagem falada na infância, constituem um material muito rico para se abordar ritmos e outros ele- 
mentos musicais. [1][10]

Alinhados a estes educadores, também defendemos que a educação em música deve promover o letramento no discurso musical. Entendemos música como uma linguagem, e por isso o objetivo da educação em música deve ser promover o letramento do estudante no discurso musical. Não consideramos a educação musical como um caminho para formar musicistas profissionais, mas sim como um meio para possibilitar qualquer cidadão compreender e se expressar no discurso musical. O letramento é um processo que visa tornar o sujeito cada vez mais capaz de se expressar naquela linguagem e compreender bem o discurso elaborado pelos outros. É um processo evolutivo de mais capacidade, como caracterizado pela Epistemologia Genética de Jean Piaget [19], pela teoria espiral de desenvolvimento musical de Swanwick e Tillman [28], e pelas fases na pedagogia Orff [10]. Todos os estudantes devem ser encorajados a participar de alguma forma do discurso musical, mesmo com diferenças na sua capacidade e talento técnico e instrumental [22].

Assumimos, também, que as práticas educativas contemporâneas devem estar fundamentadas no Construtivismo [19], devem possibilitar o aluno formular e testar suas próprias hipóteses para promover assimilaçãoacomodação em busca de equilibração, conforme teorizado por Piaget. Por isso, nesta pesquisa, projetamos práticas educacionais que oportunizam a exploração do discurso musical. Não consideramos que aprender seja uma ação passiva de memorização de informações que se faz por meio da repetição e de estímulos, como teorizado no Comportamentalismo. As práticas educacionais de música, quando fundamentadas no comportamentalismo, ao contrário do que propomos, promovem adestramento e repetição pelo ensino repetitivo e mecânico de se tocar um instrumento ou de se ler e escrever partitura, como já denunciado por Dalcroze no século passado, sendo este também o problema que atacamos com a presente pesquisa. Buscamos desenvolver uma alternativa direcionada ao construtivismo e ao sócio-interacionismo, que se mostre adequada para promover o letramento no discurso musical nas escolas brasileiras.

A partir deste quadro teórico, para projetar os Tapetes Musicais Inteligentes, consideramos as seguintes conjecturas sobre o letramento no discurso musical:

Diminuição das barreiras técnicas. Conjecturamos que a diminuição das barreiras técnicas na produção de sons facilita a exploração do discurso musical pelo estudante. Nesta pesquisa, empregamos a computação ubíqua para diminuir a complexidade para produzir sons de forma análoga ao que Orff [10] buscou ao usar instrumentos musicais como o xilofone visando possibilitar ao aluno participar mais rapidamente da produção de discurso musical.
Movimentos corporais. Conjecturamos que o corpo tem um importante papel mediador entre o sujeito e o discurso musical.

Colaboração. Conjecturamos, nesta pesquisa, que o letramento no discurso musical pode ser promovido não apenas pela mediação docente, mas também pela colaboração entre os estudantes. Esta conjectura se fundamenta nas noções de conflito sócio-cognitivo que emerge da teoria de Piaget [19], e da Zona de Desenvolvimento Proximal de Vygotsky [32]. Estas noções fundam o sócio-interacionismo ao teorizar a aprendizagem como uma consequência cultural, decorrente do contato do sujeito com outros sujeitos que também manipulam e experimentam o objeto.

A partir destas conjecturas, baseadas no quadro teórico desta pesquisa, projetamos um artefato computacional e atividades educacionais para usar este artefato em aulas de música, conforme apresentado nas próximas seções.

\section{Computação Ubíqua e Música}

Para apoiar o ensino de música nas escolas brasileiras, desenvolvemos um artefato baseado em computação ubíqua com o intuito de facilitar a produção dos sons de diversos instrumentos sintetizados no computador. Consideramos esta proposta viável levando em conta que nas escolas públicas brasileiras, de acordo com o resumo técnico do Censo Escolar da Educação Básica de 2013 [4], $82 \%$ dos estudantes têm acesso à internet e $81 \%$ têm acesso a laboratórios de informática, e na rede particular, os índices são $97 \%$ e $76 \%$ respectivamente.

A educação se transforma com as novas tendências tecnológicas. Exemplos significativos são as iniciativas OLPC (One Lap Top Per Child) [17] desenvolvido pelo MIT, e UCA (Um Computador Por Aluno) adaptado pelo MEC para as escolas brasileiras [29]. O uso de computadores e o maior acesso à internet nas escolas também indicam uma apropriação da escola brasileira das novas tecnologias computacionais.

A escola deve se adaptar e fornecer ao estudante maneiras de vivenciar a música e de poder se expressar através do discurso musical, sempre respeitando sua realidade cultural. Atualmente grande parte dos estudantes já absorveu as inovações tecnológicas do século XXI em seu cotidiano, por exemplo, por meio do uso de redes sociais e da produção e manipulação de textos, sons e vídeos. A computação ubíqua tem potencial para ser um elo entre a escola e a realidade cotidiana dos estudantes.

A sociedade, atualmente, está iniciando a terceira era da computação, que é caracterizada pela situação em que cada pessoa possui vários dispositivos computacionais [34]. O cenário visualizado por Weiser [8] é de um mundo com dispositivos eletrônicos em todos os lugares (ubí- 
quos), em grande quantidade, baratos, conectados em rede, fixos ou móveis, embutidos em objetos que cercam a vida cotidiana, como fogões, geladeiras, telefones, bicicletas, entre outros. Esses dispositivos estão presentes no local em que são necessários, sendo discretos visualmente e em seu comportamento, de forma a só serem percebidos e atuarem quando necessário [8].

Existem diferentes pesquisas para a utilização de computação ubíqua envolvendo dispositivos móveis e objetos inteligentes para dar apoio à produção sonora e também à educação musical. Um exemplo é um artefato que simula um instrumento tradicional, como a guitarra elétrica ou o violão, através de sensores e de um microprocessador fixados em uma vassoura [36]. Outro exemplo é o uso de gestos para manipular o ambiente sonoro através de captação de imagens da movimentação das crianças [33]. Uma mesa multitouch foi desenvolvida para que mais de um usuário possa interagir através de toques para a obtenção de sons sintetizados através de algoritmos que emulam instrumentos percussivos [20].

No trabalho de Zhou et al [37] é proposto um sistema que integra professor e alunos via smartphones com fones de ouvido, possibilitando diferentes configurações entre os estudantes para produzir música, seja dividindo a sala em grupos que podem tocar isoladamente ou juntos. Os pesquisadores isolam os alunos uns dos outros utilizando os fones de ouvido, portanto, os membros de um grupo podem praticar suas atividades musicais ouvindo uns aos outros e sem interferências dos demais grupos ou de sons do ambiente. Adicionalmente, eles também não geram som para o ambiente.

No trabalho de Shahar [25] foi desenvolvido um artefato, chamado de SoundStrain, que classificou como uma ferramenta tangível de composição musical. O artefato consiste em células cilíndricas que são compostas de uma estrutura plástica impressa em 3D que é envolta em um tecido elástico que, por sua vez, permite diferentes deformações da célula. Se a célula é esticada, são feitas alterações na natureza temporal e rítmica da frase melódica. Quando a célula é torcida, são feitas alterações de natureza harmônica na frase contida na célula. As células podem ser conectadas umas às outras permitindo a colaboração entre usuários.

Os Tapetes Musicais Inteligentes, desenvolvidos na pesquisa aqui apresentada, constituem um artefato que difere dos demais por um conjunto de características: seu objetivo é educacional, ao contrário de Zhang et al [36], Volpe et al [33] e Rhen et al [20], que são voltados para a execução de música. Diferentemente de Zhou et al [37], que supõe que os alunos tenham smartphones, nosso artefato foi concebido e desenvolvido no atual cenário da computação ubíqua, sendo promovida inteligência a objetos (tapetes) confeccionados utilizando materiais facil- mente encontrados no mercado e a baixo custo para que possa ser adquirido pelo professor ou pela escola. Também de forma diferente dos trabalhos apresentados, o artefato proposto nesta pesquisa busca evitar a necessidade de longo aprendizado técnico para a produção dos sons. Diferentemente de Shahar [25], este trabalho privilegia o uso dos movimentos corporais na aprendizagem musical, possibilita a colaboração entre os participantes, oferece maior grau de autonomia aos usuários, e também foi estudado no contexto educacional em sala de aula e não apenas como uma ferramenta de composição. Adicionalmente, o artefato proposto, de acordo com as propostas de Dalcroze e Orff, está associado a atividades que utilizam o próprio corpo e o corpo de outros estudantes para a produção sonora, o que não é contemplado em todos os trabalhos aqui relacionados. Por último, o artefato aqui proposto, possibilita atividades que seguem os princípios da aprendizagem colaborativa [3].

\section{Metodologia}

A presente pesquisa foi concebida com base no paradigma Design Science (DS) [26], que é a Ciência do Artificial, em que se faz pesquisa científica sobre artefatos. O método utilizado foi Design Science Research (DSR)[11, 12], que se tornou amplamente aceito na área de pesquisas em Sistemas de Informação.

\subsection{Método DSR}

No método DSR, é preciso atentar para dois ciclos que se relacionam: um sobre o projeto do artefato (Design) visando resolver um problema real em um determinado contexto, e outro sobre teorias científicas relacionadas ao comportamento humano. Conforme representado na Figura 1, as teorias científicas subsidiam o projeto do artefato; e o uso do artefato, por sua vez, possibilita investigar as conjecturas teóricas que subjazem o artefato.

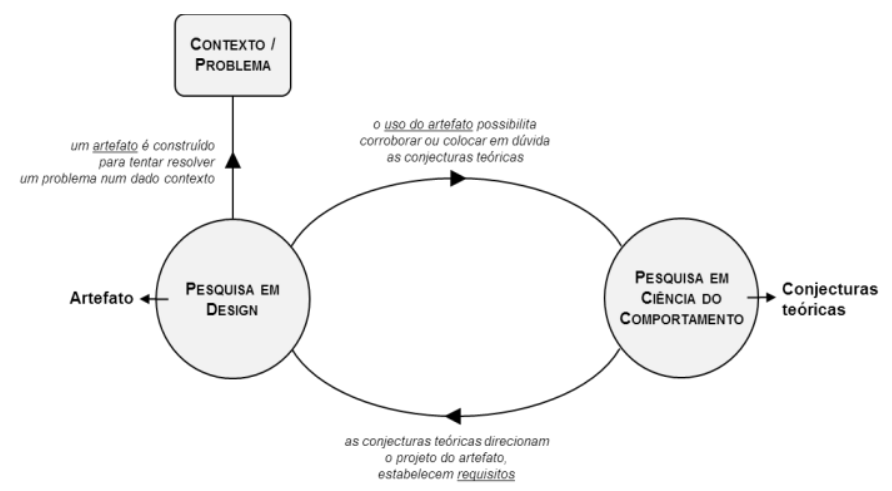

Figura 1: Método Design Science Research - adaptado de [11]

Como representado na Figura 2, na presente pesquisa partimos da premissa que a educação musical deve promover o letramento no discurso musical, e a partir desta 
premissa, conjecturamos que o letramento no discurso musical é facilitado pela diminuição das dificuldades técnicas para a produção de som impostas pelos instrumentos musicais tradicionais, pelo uso do corpo e movimento, e pela colaboração entre os estudantes. Destas conjecturas sobre o comportamento humano (sobre como os sujeitos aprendem música) definimos requisitos para o projeto do artefato. Outros requisitos vieram do modelo de aceitação de tecnologia UTAUT2 [30] (abordado na próxima subseção): performance (deve possibilitar o estudante explorar o discurso musical), esforço (deve ser fácil de ser usado), motivação hedônica (o uso deve ser agradável) e custo (deve ser barato). Com base nestes requisitos, os tapetes musicais inteligentes foram projetados para apoiar o ensino de música nas escolas brasileiras, que é o contexto no qual desejamos contribuir: propomos uma alternativa para o ensino de música que não seja baseada no comportamentalismo, que não enfatize o ensino da técnica mecânica de produção de som por meio de instrumentos musicais tradicionais.

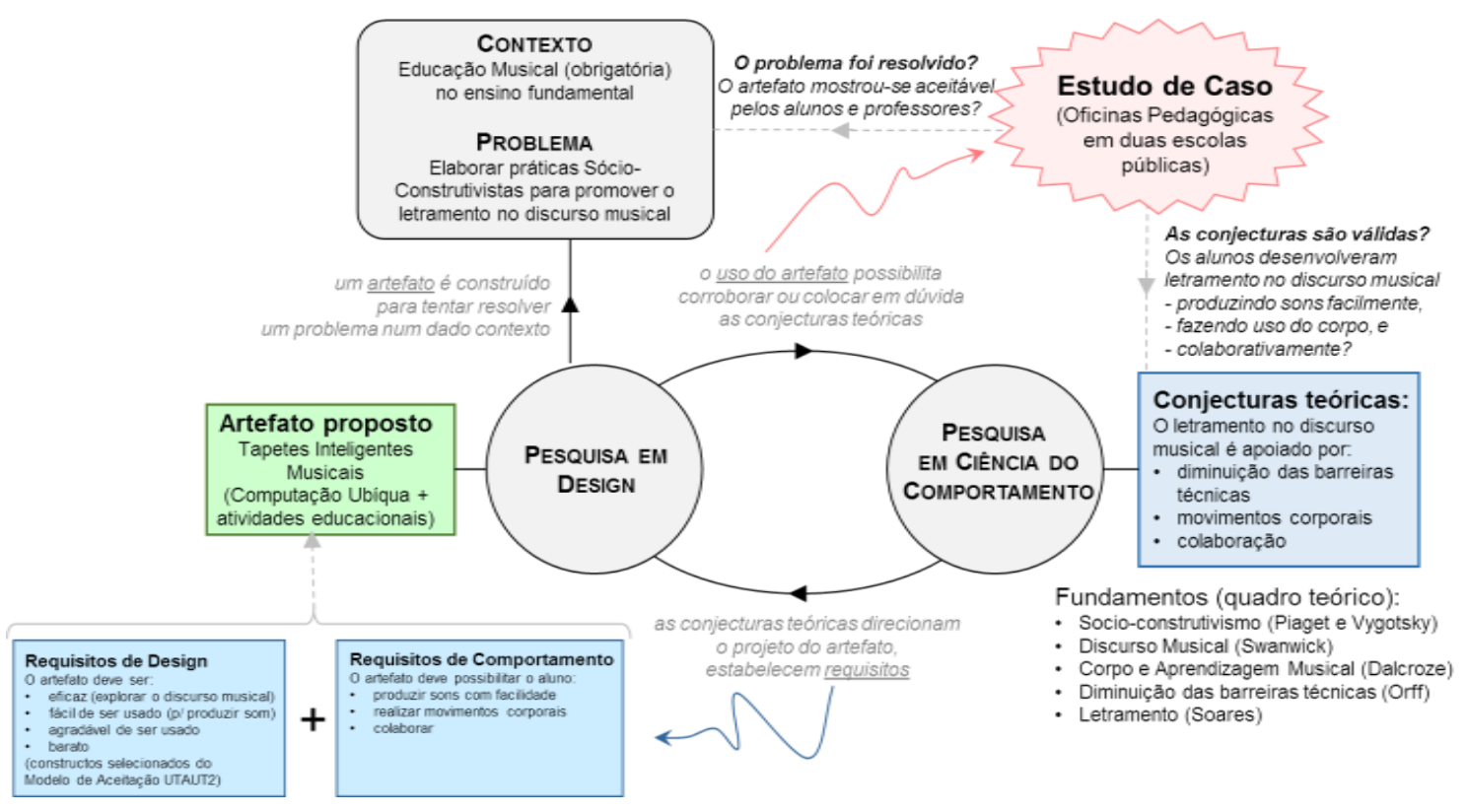

Figura 2: Método da DSR aplicado a esta pesquisa

Para avaliar o artefato, analisamos seu grau de aceitação pelos alunos, professores e pela escola - se o artefato não for aceito por todos estes usuários, deve ser considerado inadequado.

$\mathrm{O}$ uso do artefato também possibilita avaliar as conjecturas teóricas que fundamentaram o seu desenvolvimento. Com o ciclo de pesquisa em comportamento humano, busca-se gerar conhecimento sobre o comportamento das pessoas ou das organizações que lidam com a tecnologia estudada. Nesta pesquisa, a partir do uso do artefato, buscamos avaliar as seguintes questões sobre as conjecturas teóricas (fundamentadas nas teorias de Vygotsky [32], Piaget [19], Orff [10], Dalcroze [6] e Swanwick [28]):

- A diminuição das barreiras técnicas para a produção de som facilita o aprendizado?

- O uso do corpo e de movimentos corporais apoiam a aprendizagem?
- A colaboração entre os alunos apoia a aprendizagem?

A avaliação do artefato e das conjecturas teóricas pode ser realizada por diferentes métodos, como Experimento, Estudo de Caso, Pesquisa-ação entre outros [7]. Para investigar a aceitação do artefato e as conjecturas teóricas que subjazem seu projeto, optamos por adotar o método de pesquisa empírica Estudo de Caso [8, 33] seguindo uma abordagem qualitativa com posição epistemológica interpretativista [8].

\subsection{Constructos do UTAUT e UTAUT2 para Avaliação da Aceitação dos Tapetes Mu- sicais Inteligentes}

Venkatesh e colaboradores [31] realizaram uma revisão sobre a literatura referente a modelos de aceitação de tecnologia. Foram analisados 8 modelos proeminentes: Teoria da Ação Racional (TRA), Modelo de Aceitação de Tecnologia (TAM), Teoria do Comportamento Planejado 
(TPB), um modelo que combina o TAM e o TPB, Teoria da Difusão de Inovações, Teoria Social Cognitiva, Modelo Motivacional (MM) e o Modelo de Utilização PC (MPCU).

Posteriormente à análise dos modelos, foi feita uma comparação empírica entre os mesmos. A partir desta comparação os autores formularam um novo modelo, o UTAUT, Teoria Unificada de Aceitação e Uso de Tecnologia (Unified Theory of Acceptance and Use of Technology) [31], e também o validaram empiricamente comparando-o com os 8 modelos analisados anteriormente. O modelo UTAUT foi desenvolvido para possibilitar investigar a aceitação e uso de tecnologias em um contexto empresarial, sendo considerados quatro construtos: Expectativa de Performance, Expectativa de Esforço, Influência Social e Condições Facilitadoras. Os três primeiros construtos influenciam o Comportamento Intencional, que é outra variável que influencia a Intenção de Uso. Já o construto Condições Facilitadoras influencia diretamente a Intenção de Uso.

Posteriormente, Venkatesh e colaboradores [30] propuseram uma extensão do UTAUT adicionando outros três construtos que influenciam a aceitação e uso de tecnologias por consumidores: Motivação Hedônica, Preço e Hábito. Com base no modelo UTAUT2 [30], consideramos que o artefato Tapetes Musicais Inteligentes deveria satisfazer os seguintes requisitos: ter boa performance (possibilitar explorar adequadamente o discurso musical), baixo esforço de uso (ser fácil de usar), promover motivação hedônica (ser legal de usar), e baixo preço. Não consideramos Hábito como um constructo relevante para a adoção do artefato aqui proposto. Sobre o constructo Influência Social, consideramos que existe uma certa pressão da sociedade, dos pais e dos alunos, para que a escola faça uso das tecnologias computacionais na educação, e neste sentido, o fato de estarmos projetando um artefato computacional ubíquo qualquer já corroboraria para a intenção de uso; por isso, este constructo também não foi investigado no estudo com o artefato projetado, embora influencie positivamente a sua adoção.

\subsection{Estudo de caso}

Foi planejado um estudo de caso a ser realizado em duas escolas, onde seriam realizadas atividades com o uso dos Tapetes Musicais Inteligentes em algumas aulas de Música. Em cada turma, foi planejada a realização de uma oficina pedagógica com o uso do artefato. Segundo Candau [2], oficinas pedagógicas são atividades formativas realizadas em espaços e em grupos com um caráter interativo e dialético. Os trabalhos de formação de conhecimento nas oficinas pedagógicas acontecem em um ambiente com as seguintes características: "espaço de construção coletiva de um saber, de análise da realidade, de confrontação e intercâmbio de experiências, de exercí- cio concreto dos direitos humanos. A atividade, a participação, a socialização da palavra, a vivência de situações concretas através de sócio dramas, a análise de acontecimentos (...) são elementos presentes na dinâmica das oficinas" [2].

Em Estudo de Caso, é desejável a realização da triangulação de dados a partir de múltiplas fontes de evidência [35]. Nesta pesquisa, optamos por empregar a observação participante para a produção de dados sobre as atividades realizadas com o uso do artefato em sala pelos estudantes e professores, sendo as aulas gravadas com 2 câmeras para apoiar posteriormente as observações diretas realizadas. Além da observação participante, foram coletados dados por meio de questionário e sessão de grupo focal com os alunos, e entrevistas com os professores. O questionário foi aplicado ao final da última atividade com o objetivo de levantar o perfil da turma e identificar o que os estudantes acharam das atividades educacionais com o uso do artefato. Foi também planejado um grupo focal com os estudantes para que todos pudessem discutir juntos as seguintes questões:

- O que você achou das atividades feitas com o equipamento?

- Você teve alguma dificuldade para usar o equipamento?

- O que você aprendeu nas atividades?

- Você gostaria de fazer outra aula com o equipamento?

Também foi planejada uma entrevista semiestruturada com o professor de Música de cada turma para investigar o que eles acharam do artefato e das atividades realizadas. A técnica de coleta de dados por meio de entrevista baseou-se no Método de Explicitação do Discurso Subjacente, MEDS [16]. Os tópicos da entrevista também foram baseados nos construtos do modelo de aceitação de tecnologia UTAUT2 [30].

\section{Artefato desenvolvido}

Nesta Seção apresentamos o artefato elaborado e as atividades educacionais projetadas para o uso do artefato em aulas de música.

\subsection{Tapetes Musicais Inteligentes}

Foram pesquisadas diferentes tecnologias ubíquas para possibilitar uma alternativa aos instrumentos tradicionais que usasse o espaço da sala e os corpos dos estudantes (através de gestos como o bater de palmas) e que possibilitasse a colaboração. $\mathrm{O}$ artefato desenvolvido nesta pesquisa, denominado Tapetes Musicais Inteligentes, é composto de um software e um hardware que, combinados, possibilitam a produção sonora de forma simples e sem as demandas técnicas características dos instru- 
mentos musicais tradicionais. A solução encontrada surgiu da conjugação do hardware Makey Makey [15], do software soundplant [27] e de pisos emborrachados, que atende aos requisitos de facilidade de reprodução e baixo custo, e propicia um cenário potencialmente instigante para os estudantes. $\mathrm{O}$ artefato possibilita que as atividades educacionais sejam realizadas a partir do toque do estudante no corpo de outros estudantes - Figura 3.

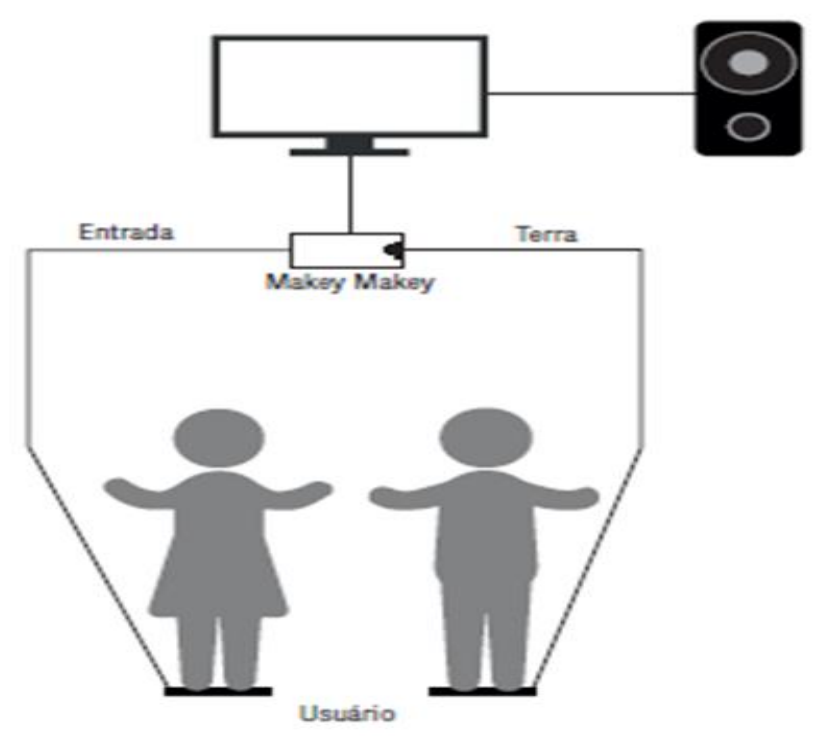

Figura 3: Componentes dos Tapetes Musicais Inteligentes

Quando um estudante em pé sobre um piso-sinal toca num estudante ligado ao piso-terra, o circuito é fechado (como um botão de liga e desliga) e o comando para a execução do som armazenado no computador é disparado. O processamento dos sons e seu gerenciamento são feitos em um computador na mesa do professor. Os sons são emitidos por uma caixa de som ligada à saída de áudio do computador para que o professor e os estudantes possam ouvir as composições e performances coletivas. $\mathrm{O}$ acionamento dos sons depende da estrutura de contatos que será instalada para possibilitar, através do Makey Makey, que os estudantes possam usar seus corpos para interagir uns com os outros.

\subsubsection{Hardware "Makey Makey"}

O Makey Makey tem como característica inovadora poder fechar contato com materiais pouco condutivos como massa de modelar, frutas e corpo humano. O Makey Makey possui 18 entradas digitais diferentes que funcionam como 18 botões. Ao se fechar o circuito entre uma entrada e o terra com um material minimamente condutivo, um sinal referente à entrada associada à determinada tecla do teclado ou ao controle do mouse é enviado para o computador como, por exemplo, barra de espaço ou click do botão direito do mouse. Dessa forma, o comando associado a cada tecla ou ao mouse é execu- tado.

O custo do Makey Makey é baixo quando comparado ao de um computador. Pela internet, pode ser comprado no exterior por US\$ 50,00 [13].

\subsubsection{Software "soundplant"}

Utilizamos o software "soundplant" [27], que tem uma versão gratuita disponível na web. Este software possibilita endereçar arquivos de áudio para diferentes teclas do teclado. Uma vez preparados os arquivos sonoros ".wav", basta arrastá-los para as teclas desejadas sobre a interface gráfica do software. A partir desta configuração, aquele som é executado toda vez que a tecla for acionada, seja diretamente pelo teclado ou indiretamente pelo Makey Makey.

\subsubsection{Pisos}

Foram projetados pisos que o estudante, descalço ou de meias, deve pisar. Os pisos, distribuídos estrategicamente no chão da sala de aula, estão ligados aos fios que levam o sinal até o Makey Makey. O material escolhido para os pisos foi a placa EVA no formato quadrado (Figura 4). É importante que os pisos sejam de material isolante para evitar fechamento de circuito entre o piso e o chão como um falso terra, disparando assim o comando quando não há interação entre os estudantes. Cada piso é ligado por meio de um fio que segue pelo chão da sala sob fitas adesivas até uma entrada da placa Makey Makey (entrada de sinal ou terra). O fio que sai de cada piso EVA é preso passando-o por baixo do piso e chega à parte superior do piso para fazer contato com um papel laminado. Este papel laminado oferece a área de contato dos pés dos estudantes com o fio. O papel laminado é preso no piso de EVA com fita adesiva.

Com relação à disposição física (Figura 4), os pisos foram projetados de maneira a alternar um piso terra cercado de pisos de entrada. Desta forma é possível tocar um som quando um estudante sobre um piso-sinal toca em um estudante sobre um piso-terra (ou vice-versa).

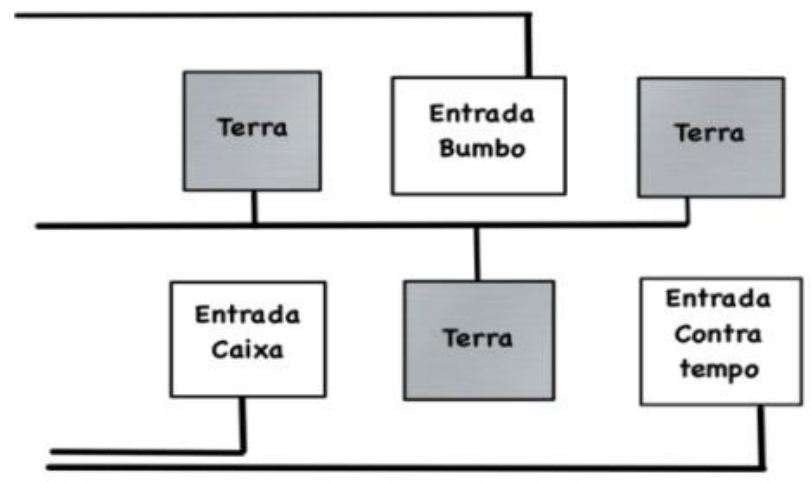

Figura 4:Esquema de funcionamento do artefato 
Os pisos de EVA são facilmente adquiridos no mercado. Fios, papel laminado e fita crepe ou isolante também são materiais de baixo custo, facilmente adquiridos e comumente encontrados em escolas.

\subsection{Atividades Educacionais Propostas para o Uso do Artefato}

As atividades educacionais propostas nesse trabalho para serem usadas com o artefato têm os seguintes requisitos: devem abordar elementos do discurso musical e oferecer um espectro abrangente de sonoridades; maior facilidade de produzir e acionar sons em comparação aos instrumentos musicais tradicionais; criação de uma alternativa sonora não excludente aos instrumentos musicais tradicionais; possibilidade de instigar a participação dos estudantes; uso do corpo e gestos para o acionamento sonoro; colaboração entre os participantes; facilidade de reprodução da atividade por um professor com pouco conhecimento de computação e com recursos financeiros reduzidos; possibilidade de abordar a apreciação, a execução e a composição musical pelos estudantes - estes 3 elementos da educação musical estão presentes nas ideias de Swanwick [28], Orff [10] e também nos parâmetros curriculares nacionais, os PCNs do MEC [18].

Para usar os Tapetes Musicais Inteligentes no contexto de aulas de música, foram elaboradas as atividades educacionais descritas a seguir.

Atividade Rítmica: aborda o pulso e seus múltiplos na composição de ritmos e a apreciação de sons característicos (timbres) de diferentes instrumentos usados no acompanhamento rítmico da bateria (bumbo, caixa e contra tempo). Esta atividade rítmica utiliza 3 pares de pisos com um som de bateria para cada par (bumbo, caixa e contratempo). Os estudantes se revezaram nos pares até que toda a turma tenha experimentado o artefato e produzido os sons solicitados (Execução). Três linhas rítmicas devem ser apresentadas aos estudantes apenas com o bater de palmas para, em seguida, elas serem executadas por meio do artefato (Apreciação). As três linhas rítmicas são construídas (Composição) para acompanhar as músicas trabalhadas pelos professores de cada escola.

Atividade Melódica: aborda a escuta de diferentes instrumentos musicais (contrabaixo e violino) e a percepção da escala maior acompanhada da execução de melodias cíclicas (Ostinatos) entre grupos de estudantes. Nesta atividade são distribuídos 10 pares de pisos referentes a 10 notas de violino (C3 a E4). Primeiramente deve ser solicitado aos estudantes que toquem as notas na sequência da mais grave para a mais aguda, acompanhando o pulso dado por palmas feitas pelo professor. Em seguida, 2 grupos, cada um com 5 pares de pisos, ficam encarregados de criar sequências melódicas (Composição) para que a turma possa apreciar suas composições (Aprecia- ção). As sequências são executadas seguindo a pulsação feita pelo professor e com as palmas para depois ser dada maior liberdade rítmica aos estudantes (Execução).

Atividade de Acordes: aborda a percepção da diferença entre nota musical e acorde, o conceito de acorde tocado com suas notas simultaneamente em sequência (arpejo) e o acompanhamento harmônico de melodias (Apreciação). Deve ser utilizada a mesma estrutura de 10 pares de pisos como na atividade melódica. Cada grupo de 5 pares contém, separadamente, as 4 notas de uma tétrade (acorde com 4 notas), sendo uma nota por par de piso. O último par de pisos contém o acorde com as 4 notas tocadas simultaneamente. As notas do acorde devem ser arpejadas pelos estudantes dos 4 primeiros pisos e, depois, o quinto par toca o acorde completo dando a percepção harmônica do acorde em relação ao arpejo (Execução). Para esta atividade são usados sons de piano. Primeiramente o ritmo é fixo com a pulsação e, posteriormente, é dada liberdade aos estudantes. Em um segundo momento dessa atividade, muda-se os sons dos pares de pisos. Um grupo de pisos contém 3 sons de acordes $(\mathrm{C}$ tríade, $\mathrm{F}$ tríade e $\mathrm{G}$ tríade) distribuídos em 3 pares. Dois dos cinco pares não são utilizados nessa variação da atividade. $\mathrm{O}$ outro grupo de 5 pares passa a ser configurado com 5 sons de vibrafone contendo as notas da escala pentatônica de C (C3, D3, E3, G3, A3). O professor solicita que os estudantes de cada grupo criem suas sequências livremente em relação às notas, acordes e ritmos (Composição) para que todos na turma possam ouvir uma melodia acompanhada de acordes.

Atividade Orquestra: Esta atividade tem por objetivo juntar os elementos rítmicos, melódicos e harmônicos abordados nas demais atividades e possibilitar aos estudantes acompanharem a canção trabalhada em sala pelo professor com uma base rítmica, melódica e harmônica. O foco desta atividade está na execução e na atividade rítmica, e não na composição, como proposto nas atividades melódica e harmônica. Também é objetivo desenvolver a memória melódica dos estudantes e articular a relação de acompanhador e cantor em uma canção.

Nessa atividade são distribuídos sons de diferentes instrumentos entre os pares de tapetes de maneira a possibilitar que todos os elementos rítmicos, melódicos e harmônicos abordados nas atividades anteriores sejam combinados em sala de aula. Um grupo fica com os sons da bateria, outro grupo com sons do baixo e outro grupo com sons de acordes tocados por um piano. A turma é dividida pela metade, em dois grupos, e, enquanto um grupo canta a canção, o outro grupo acompanha com os sons dos instrumentos da bateria, do baixo e acordes. Depois é feito o revezamento entre esses 2 grupos e quem estava cantando passa a acompanhar, e quem acompanhava passa a cantar. 


\section{Avaliação}

Nesta pesquisa, era preciso avaliar 3 aspectos: a adequação das atividades educacionais propostas com o uso do artefato (Seção 6.1), a aceitação do artefato em si
(Seção 6.2), e as conjecturas teóricas que fundamentaram o projeto do artefato (Seção 6.3). Estes aspectos puderam ser todos avaliados a partir de um estudo de caso realizado em salas de aula reais, como ilustrado na Figura 5.

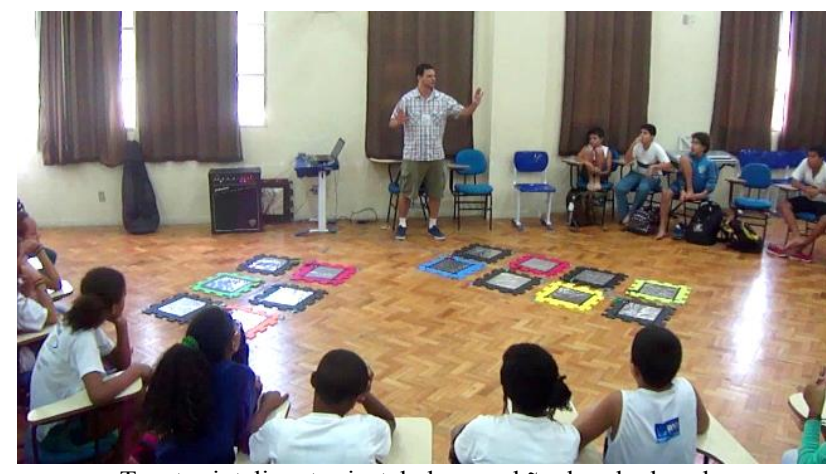

Tapetes inteligentes instalados no chão da sala de aula

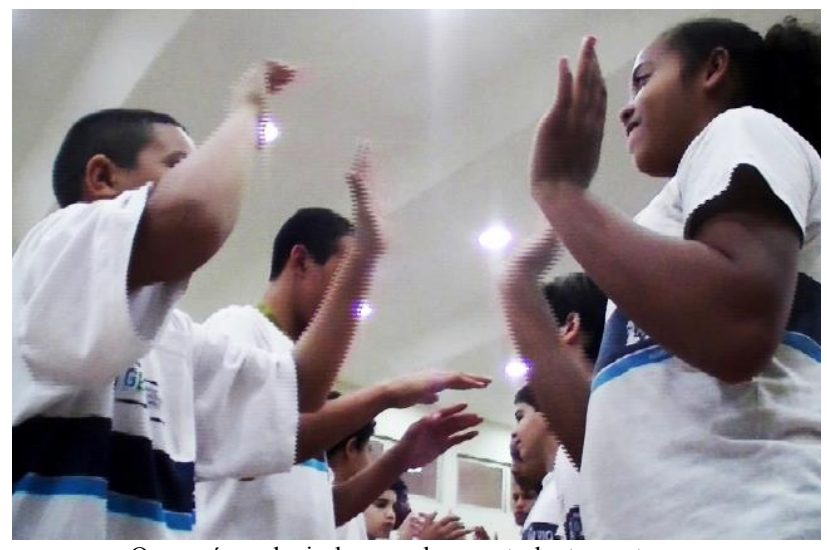

O som é produzindo quando os estudantes se tocam

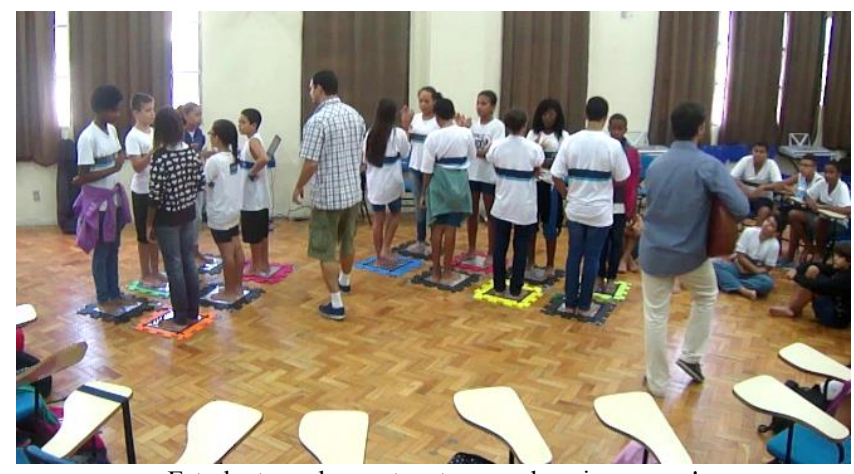

Estudantes sobre os tapetes, a aula vai começar!

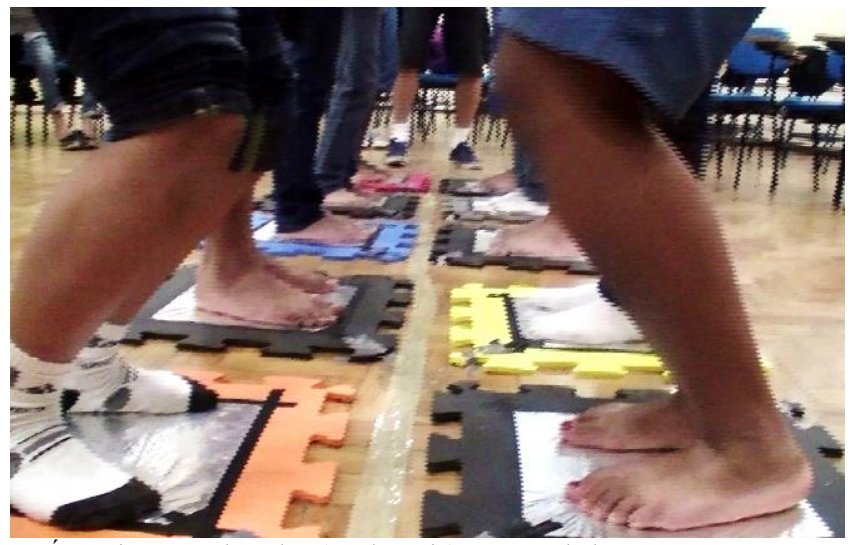

É preciso estar descalço (ou de meia) para estabelecer contato com o papel alumínio possibilitando fechar o circuito ao se tocarem

Figura 5: Uso dos Tapetes Musicais Inteligentes durante o Estudo de Caso nas aulas de música em escolas públicas

Este estudo de caso é uma investigação de caráter exploratório, não se propondo a fazer uma comparação entre estudantes utilizando os instrumentos tradicionais de educação musical e estudantes utilizando os Tapetes Inteligentes na educação musical. Esta análise pode ser feita em trabalho futuro, no entanto, enfatiza-se aqui que os autores não visam a substituir os instrumentos musicais tradicionais pelos Tapetes Inteligentes e sim apresentar o artefato estudado neste trabalho como uma alternativa não excludente aos instrumentos musicais tradicionais, e que por isso vem a somar como mais uma ferramenta de apoio à educação musical em sala de aula.

Participaram do estudo, turmas do $7^{\circ}$ ano de duas escolas da rede municipal de ensino da cidade do Rio de Janeiro - RJ (contexto): escola Ginásio Experimental Olímpico Juan Samaranch (GEO), situada no bairro de Santa Teresa, em turma com 35 estudantes; e escola Operário Vicente Mariano, situada na Comunidade da Maré, em turma com 45 estudantes. Um dos autores deste artigo, Thiago Marcondes Santos, foi o professorpesquisador que conduziu as atividades realizadas em sala de aula. Os professores de música destas turmas também participaram da oficina.

$\mathrm{Na}$ oficina pedagógica realizada em cada escola, foram realizadas as quatro atividades descritas na Seção 5.2, o que resultou em quatro unidades de análise em cada contexto (turma).(Figura 6)

Cada atividade durou aproximadamente duas aulas de 50 minutos com cada turma. Foram realizadas um total de nove aulas com cada turma, onde a primeira aula foi utilizada para a apresentação do artefato, enquanto nas oito aulas seguintes foram executadas as quatro atividades propostas. Todo o processo durou aproximadamente três meses durante o ano de 2015, uma vez que o pesquisador não podia visitar as turmas semanalmente devido a diferentes agendas das turmas em seus cotidianos escola- 
res.

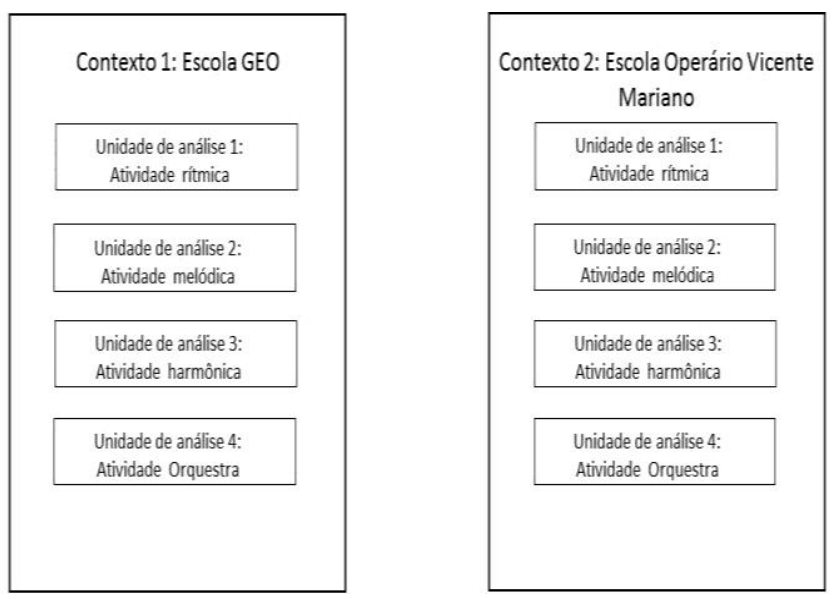

Figura 6: Estudo de casos múltiplos e integrados: 2 contextos e 8 unidades de análise pareadas

\subsection{Avaliação das Atividades Propostas}

Atividade Rítmica: Ao analisar os dados produzidos com a observação participativa na Atividade Rítmica nas 2 turmas, foram encontrados indícios de que estudantes sem muita experiência com o artefato conseguem produzir sons sem dificuldades técnicas. $\mathrm{O}$ artefato foi considerado, pelos estudantes, como um instrumento musical diferente. De fato, os Tapetes Musicais Inteligentes se constituem num instrumento sonoro que possui suas características particulares e demandas técnicas para a produção de som como qualquer outro instrumento. Após refletir sobre como os estudantes usaram o artefato, pude concluir já nesta primeira atividade que a diferença para os instrumentos tradicionais reside no fato do artefato possuir demandas técnicas menores e que são passíveis de serem entendidas e executadas em curto tempo por usuários inexperientes.

As duas turmas conseguiram produzir os sons da atividade sem dificuldade. Erros aconteciam, mas após uma breve orientação, todos os estudantes conseguiam executar os sons. No entanto, o fato de produzir um som não é condição suficiente para que o discurso musical ocorra. As questões referentes à quando produzir o som e qual som produzir ainda estavam sendo aprendidas pelas turmas. Foi possível observar que, ao lidar com estas questões, os estudantes não tinham problemas com a técnica de produção dos sons e assim podiam se concentrar mais na melhoria de sua execução do discurso musical.

Durante a Atividade Rítmica, os estudantes conseguiram produzir os sons, mas a precisão de como usar os sons ainda estava sendo adquirida pela prática com o novo instrumento. Problemas como o uso de gestos grandes, implicando em atrasos na execução das intenções sonoras dos estudantes; erros na qualidade dos toques entre os estudantes, implicando em disparos de loops dos áudios ou adiantamento e atrasos dos sons desejados dentro do discurso musical, foram observados nas 2 turmas. Isso indica que a questão relativa à diminuição da barreira técnica para a produção sonora está ocorrendo com o artefato, pois o autor que conduziu a atividade apenas teve que indicar os momentos e as estratégias de movimentos para a produção sonora dos estudantes dentro do discurso musical. Não houve a necessidade de mostrar muitas vezes como se produz o som no artefato. Todos os estudantes, ao término da primeira atividade, a Rítmica, já sabiam como produzir som pelo artefato.

A turma da escola GEO mostrou-se mais participativa e colaborativa: os estudantes que não estavam operando o artefato ajudaram, com gestos e dicas corporais, os colegas que estavam sobre os tapetes. Isto não foi observado na escola Operário Vicente Mariano, onde a colaboração se estabeleceu entre os estudantes que estavam usando o artefato, mas não com os outros estudantes que observavam a atividade.

Na escola GEO também houve uma exploração do artefato por estudantes que desejavam fazer sons sem a ajuda de um colega, e então fechavam os contatos entre os tapetes terra e entrada usando seu próprio corpo (por exemplo, com um pé em cada tapete). Nesta primeira atividade, este comportamento não foi observado na escola Operário Vicente Mariano.

Os estudantes da escola GEO também utilizaram o corpo e seus movimentos para alcançar precisão no discurso musical. Diferentes duplas de estudantes criaram diferentes estratégias de movimentos. Se em um primeiro momento o autor que conduziu a atividade apoiou os estudantes que tinham dificuldades iniciais, como erros de toques ou posicionamento nos tapetes, depois de entendido o processo de produção sonora no artefato, os estudantes já negociavam entre seus pares e criavam suas próprias estratégias de movimentação e encaixe dos ritmos na atividade proposta. Os estudantes da escola Operário Vicente Mariano usaram seus corpos e movimentos para alcançar os objetivos da Atividade Rítmica, mas essa exploração dos movimentos entre os estudantes foi mais tímida comparada à escola GEO.

O entendimento dos ritmos e sua sobreposição não foi igual para todos os estudantes, mas, mesmo aqueles que tinham maior dificuldade, gradativamente melhoraram sua performance e se encaixaram nos demais ritmos que eram tocados por seus colegas.

Em relação à adequação do artefato às necessidades da escola e seus estudantes e professores foi observado, na Atividade Rítmica, que o artefato tem flexibilidade em sua configuração espacial e possibilita que os estudantes participem de forma ativa e engajada nas atividades. $\mathrm{O}$ 
artefato também possibilita que a troca do grupo de estudantes para execução da atividade seja rápida e dinâmica, por volta de apenas 1 minuto.

Atividade Melódica: Foram observados alguns padrões que já haviam sido detectados anteriormente na Atividade Rítmica. A produção dos sons não foi um problema, embora nas duas turmas ocorreram alguns poucos casos de estudantes que não conseguiam tocar o som no momento correto, pois estavam desatentos. Em relação à falta de atenção, a turma da escola GEO geralmente conseguia ter mais concentração que a turma da escola Operário Vicente Mariano. Novamente houve, na escola GEO, comunicação e interação entre estudantes que não estavam no artefato com aqueles que estavam tocando pelo artefato. Na escola Operário Vicente Mariano, mais uma vez não foi observado este tipo de interação entre os estudantes que usavam o artefato e os que aguardavam sua vez para usar o artefato.

Um indício da facilidade de produção sonora pelos estudantes, em ambas as escolas, é que nesta segunda atividade havia estudantes que tocavam seus sons antes da hora certa da progressão de notas. A antecipação de suas execuções indica uma facilidade de produção sonora, pois, se o som fosse de difícil produção, as notas atrasariam.

Os estudantes da escola GEO já controlavam com mais segurança suas ações na produção dos sons, enquanto na escola Operário Vicente Mariano alguns problemas de técnica, como estudantes que pisavam fora dos tapetes e fechavam o circuito sem querer, ainda ocorriam e prejudicavam a precisão dos exercícios trabalhados em sala.

$\mathrm{Na}$ escola GEO os estudantes que observam a atividade estavam mais atentos ao que seus colegas estavam fazendo no artefato e isso impactou no tempo necessário para se conseguir aumentar a precisão na execução dos seus sons.

Nesta segunda atividade, foi possível sair de um contexto de menos liberdade de produção sonora, como no aquecimento onde os estudantes seguem o ritmo e também a sequência determinada para a atividade, para um contexto de mais liberdade, onde, apesar de manterem as restrições de ritmo, os estudantes já selecionam as combinações de notas. Esta atividade possibilitou a autoria colaborativa do discurso musical por meio da composição de sequências melódicas pelos estudantes usando o artefato.

A utilização do corpo e dos movimentos corporais foram observadas nas duas escolas e um número maior de estudantes passou a criar estratégias de movimentos para apoiar a execução da Atividade Melódica. Estudantes que antes se movimentavam mais timidamente, começaram a explorar mais seus gestos e a encaixar coreografias com seus pares para alcançar seus objetivos.

Atividade Harmônica: A atividade transcorreu bem nas 2 escolas e mostrou que o artefato pode ser adaptado para diferentes demandas na sala de aula. Nesta atividade, a turma da escola Operário Vicente Mariano tinha um número reduzido de estudantes e não foi possível usar todos os pares de tapetes. No entanto, isso não prejudicou a atividade uma vez que a configuração dos tapetes foi adaptada para que um grupo de 3 estudantes e o professor-pesquisador que conduzia a atividade pudessem tocar os sons sem a ajuda de um colega. Apesar de ter diminuído o potencial de colaboração, ainda assim foi necessária a negociação das sequencias entre todos os estudantes da turma.

Devido à melhora na atenção dos estudantes para a execução das atividades, desde a Atividade Rítmica até a Atividade Harmônica, foi possível concluir que o artefato e as atividades possibilitaram a produção sonora e também possibilitaram aos estudantes criar uma boa referência para desenvolver a concentração e a escuta tanto individual quanto coletiva. Os estudantes comparam e reagem à sobreposição de suas linhas melódicas, rítmicas e harmônicas com as demais linhas produzidas pela turma. A cada atividade era introduzido um novo elemento do discurso musical e os estudantes tinham que aumentar sua atenção para dar conta das demandas contidas nas atividades. Apesar de erros ocasionais, era nítida a melhoria das habilidades técnicas no uso do artefato.

Na turma da escola GEO, um grupo de estudantes que estava tocando os tapetes dos acordes se sentiu tão capaz de usar o artefato que um dos estudantes solicitou ao autor que conduzia a atividade que eles fizessem ritmos diferentes da pulsação dada por ele. O grupo então tocou um ritmo derivado dos ritmos trabalhados na Atividade Rítmica, mostrando sua apropriação do artefato e do conteúdo abordado nas atividades anteriores. Desta forma, os estudantes dialogaram com materiais trabalhados em atividades anteriores. Foi observado que, aos poucos os estudantes se sentiram encorajados a criar suas sequências com seus próprios ritmos.

$\mathrm{O}$ artefato também possibilitou que as produções dos estudantes, nas duas escolas, fossem gravadas para serem apresentadas a eles depois da atividade, e os estudantes adoraram escutar sua execução. Esta característica do artefato possibilita que o professor tenha, após uma atividade, um acervo de gravações com as produções dos estudantes para apoiar sua avaliação do desenvolvimento da turma, ou de estudantes específicos em um determinado tópico.

A Atividade Harmônica possibilitou aos estudantes aumentar sua autonomia dentro do discurso musical e incentivou a criação, a execução e a apreciação musical nas turmas das duas escolas. Pude observar um clima de 
competição amistosa entre os grupos de estudantes para realizar com mais precisão suas tarefas, fossem elas melódicas, rítmicas ou harmônicas.

Atividade Orquestra: Esta atividade reuniu os elementos abordados anteriormente nas outras 3 atividades ritmos, melodias e acordes - sendo aplicados à música que estava sendo trabalhada na turma de cada escola. $\mathrm{O}$ uso do corpo, sempre relevante nas atividades anteriores, também se mostrou relevante na Atividade Orquestra. Os estudantes utilizavam diferentes movimentos para encaixar seus ritmos, notas e acordes para acompanhar a parcela da turma que cantava a música trabalhada em sala.

$\mathrm{Na}$ escola GEO, foram presenciadas diferentes estratégias de uso do corpo e de colaboração entre os pares de estudantes em relação à escola Operário Vicente Mariano. Cada dupla que produzia som também produzia coreografias para facilitar a inserção dos elementos sonoros no discurso musical. Todas as estratégias passavam pelo uso e organização de gestos e combinações entre os pares de estudantes.

Uma dupla que produzia sons do contratempo, tinha que ficar um tempo sem tocar nada (pausa) para depois voltar a executar seu ritmo ciclicamente. Esta dupla preenchia o tempo de pausa com um pequeno gesto de se agachar e quando retornavam ao ponto de partida do gesto voltavam a tocar seu ritmo dando precisão ao período em que a pausa devia ocorrer. Outra dupla escolheu uma estratégia diferente para executar o mesmo ritmo do contratempo e cada estudante girava seus braços um sobre o outro, como se estivessem enrolando um fio em um dos braços, durante o período de pausa e, em seguida, repetiam o ritmo do início de seu ciclo alcançando ótima precisão.

Outra dupla de estudantes que tocava os sons da caixa fez um revezamento em seus gestos. Uma hora o som era tocado com um dos estudantes descendo suas mãos e batendo nas palmas das mãos do seu par, como nas brincadeiras de adoleta. Em seguida, eles invertiam as posições de suas mãos: quem estava com as mãos levantadas anteriormente colocava suas mãos em baixo para que o outro colega, agora com as mãos em cima, pudesse fazer o mesmo gesto.

Outras duas duplas, que tocaram o bumbo e o acorde de G7, ondulavam seus corpos em gestos dançantes que seguiam os ritmos da música e assim conseguiam manter sua precisão na execução de sua parte.

$\mathrm{O}$ artefato possibilitou que os estudantes que observavam a atividade pudessem ir testando, com seus colegas, estratégias de toques e de movimentos de seus corpos e verificando as outras abordagens usadas por estudantes que também utilizavam o artefato.

Na escola Operário Vicente Mariano, no dia da Ativi- dade Orquestra, participaram apenas 10 estudantes. Além do decréscimo do número de estudantes, neste dia a atenção dos participantes também estava baixa. Na Atividade Harmônica, os estudantes desta escola estavam mais concentrados, e a diminuição da atenção na Atividade Orquestra causou surpresa ao professor-pesquisador que conduzia a atividade. $\mathrm{O}$ professor da turma informou que, naquela semana, alguns estudantes faltaram e que, às vezes, os estudantes tinham certa dificuldade de engajamento nas atividades que ele desenvolvia em sala. $\mathrm{O}$ fato de ter diminuído o número de estudantes ao longo das 4 atividades, principalmente na Atividade Orquestra, me intrigou, assim como o comportamento mais tímido entre os estudantes que usavam o artefato e os que observavam. Os estudantes, ao usar o artefato, colaboravam e participavam, mas seus colegas que esperavam sua vez de ir para o artefato não interagiam muito entre si e com os estudantes que estavam produzindo os sons.

O professor comentou que naquela escola os estudantes tinham certo desconforto com o contato físico. Por esta escola estar localizada em uma área de altos índices de violência, muitas crianças tinham uma relação desconfiada com o contato físico e isso poderia ser a causa da diminuição gradativa do número de estudantes nas atividades. Como o artefato e as atividades privilegiavam a interação entre os estudantes e o contato físico, estes poderiam ser fatores de desconforto para alguns dos estudantes. Aliado a essas questões levantadas pelo professor da turma, no último encontro com a turma, outro problema pode ter influenciado o comportamento dos estudantes: naquele dia da Atividade Orquestra estava havendo tiroteios na comunidade desde cedo. Ao chegar à escola, não fui alertado para isso e me parecia que era um dia de aula normal. Faltando 15 minutos para o fim da Atividade Orquestra com o segundo grupo de estudantes, fui informado que o tiroteio havia voltado e as crianças deveriam ser liberadas. Isso também atrapalhou a produção de dados com o questionário e as entrevistas. Encaminhei 7 questionários, com os últimos estudantes a sair da sala, para que preenchessem em casa e depois entregassem para seu professor. Nenhum desses questionários foi entregue depois e consegui apenas os questionários de 13 estudantes que participaram da Atividade Orquestra anteriormente.

Apesar dos estudantes apresentaram menor precisão na Atividade Orquestra nesta escola, ainda assim houve estudantes que conseguiram atender às demandas da atividade de forma satisfatória. Foi percebido que 5 estudantes tiveram uma melhora de sua atenção e da colocação dos sons nos momentos certos do acompanhamento e conseguiam fazer atividades onde uma maior atenção era exigida, devido ao maior número de instrumentos sendo tocados simultaneamente. Um estudante se mostrou muito motivado e chegou a executar sozinho a 
sua parte e a de seus colegas para acompanhar o professor da turma que tocava o violão e cantava a canção: ele sentou-se no chão e conseguia tocar as notas dos baixos tocando alternadamente, e com precisão, os tapetes com sua mão.

Por fim, considero que esta atividade foi satisfatória e o artefato apoiou as aulas de música nas duas escolas, cada uma com suas características particulares, ainda que percalços tenham ocorrido durante as atividades.

\subsection{Avaliação da Aceitação do Artefato}

Esta seção apresenta uma reflexão sobre a aceitação do artefato segundo os constructos do UTAUT2.

\subsubsection{Expectativa de Performance}

Pelo que já foi discutido nas subseções anteriores, e nas observações diretas sobre as atividades com o uso do artefato, não nos restam dúvidas de que o letramento dos estudantes realmente foi potencializado pela diminuição da barreira técnica, pelos movimentos corporais e pela colaboração. Algumas narrativas dos estudantes e professores também corroboram com esta conclusão.

Pelas falas dos estudantes na escola GEO, identificamos que o artefato possibilita a exploração dos conceitos musicais de forma lúdica e participativa, deixando os estudantes interessados no processo de letramento no discurso música: "Eu achei excelente porque, além de ser divertida a aula, quer dizer, além de ser divertido, tem uma aula também. Aprendi acordes, coisas que eu não tinha escutado ainda. Como ela [uma colega] falou, também os instrumentos são tecnológicos e mais fáceis de tocar do que os outros que você tem que treinar bastante porque tudo é com treino". As atividades com o artefato possibilitaram uma vasta gama de experiências de aprendizagem entre os estudantes e o conteúdo das aulas. Alguns estudantes ressaltaram o que tinham aprendido nas atividades: "Eu aprendi os acordes, o tempo que são usados. Sei lá ... eu aprendi a tocar os instrumentos sem ter de usar os de verdade". O aprendizado do som de outros instrumentos também foi destacado por alguns estudantes: "Aprendi alguns instrumentos que eu não conhecia"; "Aprendi a marcar o tempo e também aprendi novos instrumentos".

Por outro lado, teve um estudante que considerou não ter aprendido algo: "Eu não aprendi nada porque, tipo assim, não foi nos instrumentos". A resposta deste estudante é muito interessante e mostra como existem pessoas que associam o aprendizado musical a tocar um instrumento tradicional. $\mathrm{O}$ próprio estudante admite que tocou, mas para ele, esse tocar não está relacionado à aula de música por não fazer uso de um instrumento musical tradicional.

Ao perguntar ao professor da escola GEO se ele acha- va que o artefato pode apoiar as aulas de música, ele respondeu: "Sim, pude ver isso logo depois de algumas semanas que a gente não fez atividades. Começamos a tocar alguns outros instrumentos e pegamos outra música para trabalhar e eles pegaram muito rápido. Já estávamos trabalhando a questão musical do baião e ai começamos a tocar outro baião e foi muito fácil para eles tocarem as outras coisas. Tocar o cajon, começar a ver os teclados e o violão". Esta declaração revela que o professor, assim como os estudantes, também percebe que as atividades realizadas com o uso do artefato apoiaram a aprendizagem musical. Para este professor, o artefato e as atividades também ajudaram os estudantes a usar os instrumentos tradicionais e a melhorar as execuções dos ritmos do baião em outras atividades feitas por ele.

Na escola Operário Vicente Mariano, o grupo focal e os questionários respondidos pelos estudantes mostram indícios de que o artefato e as atividades apoiam a educação musical e possibilitam aos estudantes a exploração do discurso musical. Diferentes elementos do discurso musical e diferentes instrumentos e seus timbres foram explorados, aumentando o número de experiências musicais na sala de aula. As respostas dos estudantes corroboram com a observação direta do professor-pesquisador de que o artefato e as atividades apoiaram a aprendizagem musical. Em sua maioria, os estudantes perceberam o seu aprendizado em sons de instrumentos e também nos ritmos trabalhados. Um estudante disse que "Nós aprendemos mais sons. Aprendemos a tocar músicas e ritmos diferentes". Para outros estudantes, ficou a percepção de que eles estavam aprendendo os próprios instrumentos simulados no artefato, como nesta declaração "Aprendi a tocar violão, bateria e ritmos", ou ainda este outro estudante que disse "Aprendi a tocar instrumentos como o violino". Contudo havia também estudantes que entendiam que estavam tocando os sons de determinados instrumentos por meio do artefato como evidencia esta declaração: "Aprendi a tocar os sons dos instrumentos, e é divertido".

Um estudante constatou: "Aprendi a prestar atenção $e$ a ouvir". Esta afirmação é muito importante, pois a falta de atenção na escuta foi um problema que o professorpesquisador observou ao longo de todas as 4 atividades realizadas nesta escola. $\mathrm{O}$ fato de um estudante chegar a essa conclusão sobre sua aprendizagem indica que o artefato e as atividades apoiaram o crescimento e a percepção do estudante no discurso musical.

$\mathrm{Na}$ entrevista com o professor da turma, Klaus, ao perguntar se ele achava que o artefato e as atividades poderiam apoiar as aulas de música, ele disse que " $E$ bom por um lado porque ele é um equipamento compacto que eu posso utilizar diferentes timbres, trabalhar a harmonia, trabalhar a melodia, trabalhar outros aspectos, 
trabalhar dinâmica na sala". Ele destacou a versatilidade do artefato e como o artefato pode ser explorado de diferentes maneiras para apoiar as aulas de música. Ao perguntar ao Klaus se ele achava que o artefato e as atividades podem apoiar a aprendizagem de instrumentos tradicionais ele declarou: "Pode sim. Às vezes eu não tenho um teclado na sala de aula, mas como com o computador a gente pode baixar esse recurso, ai eu posso colocar o som desse timbre para podermos trabalhar. Posso fazer uma atividade de percepção musical com eles com aquele equipamento. Eu vou colocar uma diversidade de instrumentos que não temos em sala de aula para eles. Conforme eles vão fazendo a atividade, eles vão percebendo ah isso aqui é um piano, isso aqui é um violoncelo (...) porque como não tem os instrumentos, podemos colocar outros timbres no equipamento para utilizar".

Com base nos dados apresentados, há indícios de que o artefato, juntamente com as atividades propostas, possibilitaram aos estudantes, das 2 escolas, o letramento musical seguindo as ideias de Swanwick sobre a evolução através dos planos necessários ao letramento no discurso musical. Após trabalharem com os diferentes materiais sonoros e transformá-los em elementos musicais, os estudantes ascenderam pelo modelo espiral de Swanwick [28] conseguindo se expressar através deste discurso com sua voz autoral e não meramente como imitadores ou recebedores passivos de conteúdo. Os estudantes compuseram fragmentos melódicos e conseguiram se expressar musicalmente com os materiais sonoros fornecidos.

\subsubsection{Expectativa de Esforço}

Por Expectativa de Esforço, queremos saber se os alunos e professores consideram o artefato fácil de usar, uma vez que as pessoas tendem a evitar usar as tecnologias que requerem muito esforço em sua utilização.

$\mathrm{Na}$ escola GEO, os estudantes se posicionaram com segurança quando perguntados se tiveram alguma dificuldade em usar o artefato: 16 estudantes responderam que não tiveram dificuldades, e 6 estudantes acharam que tiveram dificuldades no início, mas que estas dificuldades foram sumindo à medida que praticaram a técnica para a produção de sons pelo artefato: "No início eu me atrapalhei com o ritmo, mas depois acertei"; "No inicio minha coordenação não era boa e eu acelerava o ritmo. Depois melhorou". Mesmo tendo dificuldades iniciais, os estudantes não se sentiram intimidados em explorar o artefato: "Eu tive um pouco de dificuldade, mas não foi aquela dificuldade que pode dizer ... ah... foi muito dificil". Com a prática, os estudantes se aprimoraram na técnica para a produção de som pelo artefato, como ilustra o depoimento deste estudante: "umas vezes eu tinha dificuldade e outras não. Com o passar do tempo foi ficando mais fácil’".
Ao analisar as respostas dadas pelos estudantes no questionário para as perguntas "O que você achou das atividades?" e "O que você achou do uso do artefato nas atividades?", percebemos que os estudantes não tiveram muita dificuldade para executar as atividades e para usar $\mathrm{o}$ artefato, o que indica que o esforço para usar o artefato é baixo. Apenas 1 estudante considerou difícil o uso do equipamento nas atividades, e 3 estudantes acharam as atividades difíceis ou muito difíceis. A maioria dos estudantes considerou que o artefato tem grau de dificuldade mediano a fácil de usar, e a maioria achou as atividades fáceis ou muito fáceis.

$\mathrm{Na}$ escola Operário Vicente Mariano os estudantes também se posicionaram com segurança quando perguntados se eles tiveram alguma dificuldade em usar o artefato: 9 estudantes em 19 entrevistados disseram que não tiveram dificuldades, e 3 estudantes responderam que não sabiam. Um estudante comentou que era mais fácil tocar o artefato do que um instrumento musical tradicional: "Aqui é mais fácil. As notas já vêm praticamente prontas. Lá (instrumentos tradicionais) não, a gente tem que saber as notas de cor. Aqui achei muito mais fácil sim". Outros estudantes seguiram a mesma linha de raciocínio: "É mais fácil. Temos de usar as mãos e é mais fácil do que os outros instrumentos, que a gente precisa de mais aprendizado"; "a gente não precisa fazer tanta coisa, só usar as mãos"; "Achei fácil porque as notas já vêm praticamente prontas e também temos a ajuda do professor e lá (aula de música tradicional) tem mais dificuldade porque ainda tem que preparar as notas". Alguns estudantes disseram ter tido dificuldades no uso do artefato em um primeiro momento, mas que foi ficando mais fácil com o passar do tempo, como evidenciou este estudante: "Tive dificuldade em acertar os toques com o parceiro. No início era mais difícil e com o tempo peguei o ritmo e ai foi mais fácil".

Apesar dos estudantes terem diferentes níveis de dificuldade no uso do artefato, é importante destacar que todos conseguiram produzir sons para executar as atividades e aqueles que acharam mais difícil no início, se adaptaram rapidamente à técnica do artefato e conseguiram atender às demandas das atividades.

\subsubsection{Motivação hedônica}

Por Motivação Hedônica, queremos saber se os alunos e professores consideraram prazeroso usar o artefato, porque se a tecnologia proposta for desagradável as pessoas evitarão usá-la.

$\mathrm{Na}$ escola GEO, os estudantes ficaram surpresos como o artefato produz seus sons, o que os motivou bastante nas atividades, um indicativo de que o artefato promove Motivação Hedônica: "Para mim é um instrumento novo que eu gostei, muito muito muito!!"; "No primeiro 
momento eu achei que não ia dar certo. Eu, fazer música com as mãos!! (risos) ai depois eu fui vendo que é bem divertido e legal e a gente aprende. No início fiquei com medo de levar choque"; "Criativo. Muito ... muito .... muito .... Pra mim a gente assim que conhece esses instrumentos assim normais, tipo nada a ver né. Mas aí quando você entende ai você acha criativo. Como é que você toca uma bateria com um negócio que você só tem que pisar". Outro estudante disse entusiasmado: "Eu achei legal e diferente porque nunca usei um instrumento com tapetes e movimentos para fazer som".

Ao analisar as respostas dadas pelos estudantes no questionário, se as atividades foram desagradáveis ou agradáveis, constatamos que a grande maioria, 25 estudantes, considerou a experiência agradável ou muito agradável e apenas 3 estudantes acharam as atividades desagradáveis ou muito desagradáveis. Sobre a pergunta se as atividades foram chatas ou divertidas, a maioria da turma achou as atividades muito divertidas e apenas 2 estudantes acharam as atividades muito chatas ou chatas. Sobre a satisfação dos estudantes com a atividades, enquanto a maioria ficou satisfeita ou muito satisfeita, somente 1 aluno se mostrou pouco satisfeito.

$\mathrm{Na}$ escola Operário Vicente Mariano os estudantes estavam entusiasmados com o artefato e executavam as atividades de forma engajada e participativa, indicando que a Motivação Hedônica foi alta. Um estudante declarou: "Achei interessante, algo que nunca vimos. Achei divertido". Ao analisar as respostas dadas no questionário pelos estudantes desta escola, se as atividades foram desagradáveis ou agradáveis, apenas 1 estudante achou as atividades nem agradável e nem desagradável. Três estudantes consideraram as atividades um pouco agradáveis enquanto a grande maioria, 9 estudantes, considerou a experiência muito agradável. Sobre a pergunta se as atividades foram chatas ou divertidas, apenas 2 estudantes acharam as atividades nem chatas nem divertidas enquanto 2 estudantes acharam um pouco divertidas e a maioria, 9 estudantes, achou muito divertida. Sobre a satisfação dos estudantes com a atividades, somente 1 aluno se mostrou um pouco satisfeito e a maioria, 11 estudantes, se mostrou muito satisfeita.

\subsubsection{Condições Facilitadoras}

Por Condições Facilitadoras, queremos saber se professores consideram que há condições para se fazer uso do artefato na escola.

$\mathrm{Na}$ entrevista com o professor Felipe, da escola GEO, ele mostrou-se preocupado com as Condições Facilitadoras, pois não se julgava capaz de montar e gerenciar o equipamento com as atividades por não ter conhecimentos de informática: "a parte da montagem é que pra mim é a grande questão. Eu vi você montando e eu, como não tenho nenhuma intimidade com essa parte de eletrônica e hardware, então pra mim foi complicado. Te vi montando lá e acho que eu ficaria um pouco sem saber o que fazer se você largasse e dissesse: pô, monta ai". No entanto, ao perguntar se ele usaria o artefato se já tivesse a estrutura do equipamento montada, ele afirmou "Ai achei ótimo, porque ali você está podendo trabalhar com mais crianças e eu acho que o equipamento realmente somou".

Na entrevista com o professor Klaus, da escola Operário Vicente Mariano, ao perguntar o que ele tinha achado do uso do equipamento pelos estudantes ele disse: "Ele é um equipamento bom por um lado e complicado por outro lado. É bom por um lado porque ele é um equipamento compacto que eu posso utilizar diferentes timbres, trabalhar a harmonia, trabalhar a melodia, trabalhar outros aspectos, trabalhar dinâmica na sala. A questão complexa é a questão da instituição que eu trabalho, se ela consegue acompanhar essa tecnologia porque temos problemas na energia elétrica, por exemplo".

A preocupação deste professor não era com a possibilidade de ele ter de montar o equipamento, com aconteceu com o outro professor da escola GEO, e sim com o fato da escola não ter as condições de infraestrutura suficientes para absorver esta tecnologia. O professor viu problemas nas Condições Facilitadoras, mas não do artefato e sim da escola.

Ao perguntar se ele usaria o artefato se já estivesse montado e preparado, com as condições de infraestrutura da escola atendendo às necessidades de instalação do equipamento, ele disse: "Eu utilizaria ele como uma das minhas metodologias no ensino de música. Não usaria ele sempre. Usaria como uma ferramenta a mais. Se eu for falar de ritmo posso usar ele e também outros. Se falar de harmonia posso usar ele e outros instrumentos. Ele não é exclusivo porque na minha aula de música eu gosto de trabalhar a vivência musical de todas as formas". As palavras do professor reforçam uma preocupação, já inclusa na concepção do artefato e das atividades, que é o fato desta ferramenta ser não excludente aos instrumentos musicais tradicionais, podendo ser conjugada com outros instrumentos e dinâmicas para oferecer aos estudantes uma rica gama de experiências para apoiar o aprendizado musical.

\subsubsection{Custo}

Por Custo, queremos saber se o artefato tem boa relação custo-benefício, se o custo para sua aquisição é aceitável perante o benefício que ele pode proporcionar para as aulas de música; isto porque as pessoas evitam comprar uma tecnologia se a considerarem muito cara e com um custo que não compensa os benefícios proporcionados.

Todos os materiais envolvidos na construção do arte- 
fato são baratos e de fácil acesso no mercado. Estas características foram pensadas anteriormente para disponibilizar para as escolas e professores as condições de acesso ao artefato. $\mathrm{O}$ professor tem de usar um computador ligado a caixas de som e ter uma placa Makey Makey. Os outros materiais são encontrados em papelarias e supermercados: fios ethernet, papel alumínio, fita isolante, tapetes EVA, fita crepe. O custo do Makey Makey é US\$ 50,00 e o soundplant é um software com versão gratuita. $\mathrm{O}$ custo de um par de tapetes prontos para conectar ao Makey Makey é de aproximadamente: R\$ 25,00. Consideramos que este custo é baixo em relação aos benefícios que podem promover para as aulas de música.

\subsubsection{Intenção de uso}

Para investigar a intenção de uso, perguntamos se os estudantes gostariam de ter outra aula com o artefato.

$\mathrm{Na}$ escola GEO, 30 estudantes declararam ter interesse em ter outras aulas com o uso do artefato. Sete estudantes disseram que não gostariam de ter outra aula com o uso do artefato, sendo que apenas 2 justificaram: acharam as atividades repetitivas depois de um determinado momento, e não se interessariam em fazer mais atividades como as que participaram . Deve-se destacar que um desses estudantes também disse não ter aprendido nada, pois não foram usados instrumentos musicais tradicionais.

Em relação à escola Operário Vicente Mariano, a pergunta do questionário sobre se os estudantes gostariam de fazer outra aula com o artefato mostrou que 11 estudantes estavam interessados. Nesta escola, apenas 1 estudante disse que não tinha interesse em fazer outra aula com o artefato. Estes dados também indicam que os estudantes se interessaram pelas atividades e pelo uso do equipamento, mesmo com os problemas levantados pelo professor em relação ao uso do corpo e de interações corporais entre os estudantes.

\subsection{Avaliação das Conjecturas Teóricas}

O presente estudo de caso também nos possibilitou avaliar as conjecturas teóricas que subsidiaram o projeto dos Tapetes Musicais Inteligentes, como discutido a seguir.

Diminuição das barreiras técnicas: o artefato foi projetado para diminuir as barreiras técnicas na produção de som, pois nossa conjectura é que assim o sujeito consegue focalizar mais a atenção nos elementos do discurso musical e não no instrumento em si, potencializando a aprendizagem.

$\mathrm{Na}$ escola GEO, os estudantes acharam que o artefato possibilitou uma fácil produção de som e, assim, eles puderam focalizar a atenção no discurso musical: "Tive só de esperar o momento certo de bater. Tinha vezes que eu tinha dificuldade, mas depois eu fui pegando".

$\mathrm{Na}$ entrevista com o professor desta turma, perguntei se ele achou que os estudantes tiveram dificuldades para usar o artefato, e o professor considerou que a dificuldade para tocar pelo artefato se equivale a aprender um instrumento qualquer: "Acho que eles tiveram as dificuldades normais de se aprender um instrumento novo. Eles têm aquela trava no começo e depois vão desenvolvendo com mais facilidade". No entanto, os estudantes apresentaram uma opinião diferente, consideraram o artefato mais fácil de tocar do que os instrumentos musicais tradicionais: "Eu gostei porque é um instrumento tecnológico e mais fácil de tocar. Antes para aprender um instrumento é meio dificil, você tem que treinar. Eu gostei de participar de um experimento desses"; "Eu achei legal porque eu achei mais fácil de tocar e mais fácil de aprender. É mais fácil de prestar atenção porque os outros, os instrumentos tradicionais, a gente demora muito para aprender". Uma vez que a maioria dos estudantes tem instrumentos musicais tradicionais em suas casas, as opiniões destes estudantes estão embasadas em experiências, o que nos oferece indícios para afirmar que os estudantes, de fato, consideraram que o artefato possibilitou produzir som mais facilmente do que instrumentos tradicionais.

Os estudantes da escola Operário Vicente Mariano também se mostraram capazes de usar o artefato e não acharam difícil este processo. Nesta escola, assim como na escola GEO, os estudantes também fizeram comentários sobre o artefato e as diferentes formas de interação com este equipamento. Os estudantes comentaram que era mais fácil tocar o artefato do que um instrumento musical tradicional. O perfil em relação ao conhecimento dos instrumentos musicais nesta turma foi diferente da escola GEO. A maioria dos estudantes não possui instrumentos musicais em casa, no entanto, em suas respostas ao grupo focal, os estudantes sabiam comparar o artefato aos instrumentos musicais apresentados pelo professor Klaus, neste caso o violão, e consideraram que era mais fácil produzir sons pelos Tapetes Musicais Inteligentes.

Movimentos corporais: $\mathrm{O}$ artefato foi projetado para produzir som por meio do movimento corporal, exigindo que os estudantes se toquem, pois nossa conjectura é que o corpo é um meio para o sujeito alcançar a experiência musical, podendo ter um papel intermediador entre os sons e o pensamento.

Na escola GEO, sobre o uso do corpo na aula de música, um estudante expressou sua surpresa: "Eu aprendi a ... meio que abstrato o som que a gente fez lá porque a gente conseguia se divertir, brincar, pular e tocar no outro. Várias coisas diferentes que eu nunca tinha visto antes"; outro estudante ressaltou a dança e a brincadeira no processo de produção de discurso musical: "A gente 
pode fazer som dançando, brincando umas coisas"; outro expressou sua estranheza e surpresa: "Eu achei criativo $e$ um pouco estranho porque eu nunca tinha visto um instrumento daquele jeito onde você toca assim (gesto batendo palmas)". Um estudante até passou a ver seu corpo como um instrumento musical: "Eu aprendi que eu posso fazer música com as mãos".

O uso do corpo foi bem exercitado nas atividades, os estudantes usaram gestos para se expressar, e muitos correlacionaram os gestos com o aprendizado: " $E u$ aprendi os ritmos com movimentos do corpo"; "Eu aprendi coordenação motora, a marcar o tempo, antes eu não tocava certo no tempo. O professor mesmo reclamava que a gente acelerava o ritmo ai foi acostumando $e$ melhorando"; "Eu aprendi a coordenação motora e o tempo de cada nota (gestos de bater palmas). A sincronização é esperar o momento certo de bater".

Um estudante disse que percebeu melhoras em outras áreas diferentes da música depois de ter trabalhado nas atividades com o artefato. Para este estudante, as atividades melhoraram sua coordenação motora em atividades de educação física. "Eu aprendi a respeitar mais a hora certa de tocar. Eu também acho que foi a minha coordenação motora que eu melhorei muito. Porque na natação mesmo eu não era muito bom na coordenação motora e conforme eu fui fazendo esses tapetes eu já melhorei muito".

$\mathrm{Na}$ entrevista com o professor, Felipe indicou que os estudantes estavam utilizando seus corpos e gestos para apoiar a aprendizagem musical. Na perspectiva daquele professor, "usando o corpo, trabalhando junto, você desenvolve outras coisas além da musicalidade a questão da própria coordenação motora, o tempo que também acaba refletindo em outras áreas do desenvolvimento deles, não só no esporte como um aluno falou, mas em outras áreas de diversas maneiras".

Na escola Operário Vicente Mariano, o uso do corpo e de gestos para apoiar a aprendizagem musical ocorreu de forma menos intensa do que na escola GEO. Não observei muitas estratégias de gestos criadas pelos estudantes. Eles usavam seus corpos sim, mas porque o artefato precisava dos toques para produzir os sons. Não observei muitas estratégias de movimentos, sendo que estes se limitavam ao bater de mãos entre estudantes. Ainda assim foi possível observar algumas estratégias de movimentos e, em suas respostas do grupo focal, os estudantes faziam gestos para completar suas frases como, por exemplo, o estudante que disse "A gente tem de usar as mãos [gesto de bater palmas] e é mais fácil do que os outros [instrumentos], que a gente precisa de mais aprendizado". Ou ainda outro estudante que falou "Tive dificuldade naquele que batia assim [gestos de bater de palma com o parceiro] o bumbo. No começo, era dificil coordenar as palmas com o parceiro". Mesmo com uma gama mais reduzida de estratégias de movimentos para executar as atividades, os estudantes perceberam melhoras em seu desempenho e isto também foi observado por mim.

Outro fator importante em relação ao uso do corpo foi explicado pelo professor na entrevista: "E tem uma coisa, os alunos, principalmente ali na Maré, têm um problema muito sério com o contato físico. Tem vezes que eles são muito violentos. E aquela atividade eles têm de entender que tem de ter uma dosagem da força e eles têm que trabalhar em equipe também. Você tá no baixo, você tá na harmonia, você tá na percussão". O professorpesquisador já tinha observado que as interações e os movimentos corporais nesta turma eram mais tímidos do que na escola GEO. A realidade social da comunidade onde estes estudantes estão inseridos reflete claramente as características da turma. $\mathrm{O}$ receio do contato físico destacado pelo professor explica em parte o comportamento dos estudantes ao longo das atividades.

Colaboração: $O$ artefato também foi projetado para possibilitar a colaboração entre os estudantes, pois nossa conjectura é que a colaboração oportuniza aprendizagem. Durante a observação direta das atividades, o professorpesquisador identificou que trocas de informação foram feitas entre eles para atingir suas metas nas atividades. Ao usar o artefato, foi identificado que a colaboração acontece, além do professor com os alunos, também entre os estudantes que usam o artefato, entre os estudantes que observam as atividades, e entre estes dois grupos de estudantes (os que usam e os que observam). Pelo estudo de caso foram identificados indícios de que a colaboração entre os estudantes apoiou a aprendizagem.

$\mathrm{Na}$ escola GEO, alguns estudantes destacaram a interação que estabeleceram com seus colegas: "Eu gostei muito porque é bem ... interagi muito."; "Eu achei bem interessante (...) Ainda mais que a gente trabalha em conjunto e o som fica bem melhor. Não tem uma pessoa trabalhando sozinha. Em vez de ficar decorando, a gente já tem o ritmo e aí fica mais interessante". Estas declarações identificam o caráter sócio-construtivista na construção do discurso musical.

$\mathrm{Na}$ entrevista com o professor Felipe, ele enfatizou a importância da colaboração entre os estudantes para a aprendizagem: "Eu vi os estudantes colaborando bastante! Você pode aproveitar mais de uma criança para fazer o som. (...) O grande lance é que um estudante depende de outro estudante para fazer o som. Se um tiver mais habilidade e o outro menos habilidade, pode atravancar um pouco no começo, mas também entra a questão de que um ajuda o outro a se desenvolver".

$\mathrm{Na}$ escola Operário Vicente Mariano, o artefato possibilitou a colaboração entre os estudantes e a exploração 
do discurso musical de forma dinâmica e instigante. Os estudantes que participavam das atividades usando o artefato interagiam entre si e criavam diferentes estratégias de comunicação e negociação de suas tarefas. Em alguns momentos, estudantes trocaram as suas posições nos tapetes porque percebiam que as demandas de determinados instrumentos eram mais fáceis para eles executarem naquele momento do que as demandas do instrumento em que estavam alocados. Isto mostra indícios da natureza adaptável do artefato devido à sua configuração física. Os sons são intercambiáveis entre os participantes e, de acordo com as dificuldades e facilidades, eles podem se mover pelo artefato até encontrarem um instrumento cuja execução esteja dentro de suas possibilidades, o que não dá para ser feito com um violão ou piano ou flauta.

Ao perguntar ao professor se ele tinha observado seus estudantes colaborando ao usar o artefato nas atividades, ele disse: "Exatamente, mas ai eu achei que como foram poucos alunos eles conseguiram se concentrar um pouco melhor. Eu vi que eles realmente esperavam um e outro começarem para eles montarem o arranjo". O professorpesquisador também tinha reparado este comportamento desatento na escuta da maioria dos estudantes e apenas trabalhou com metade da turma de cada vez. Perguntando ao professor se os estudantes se concentravam nas suas aulas e ele afirmou que "Não, eles não são muito concentrados não. Eu, como professor, tenho que cativar eles, entendeu nessa (...) A música precisa de repetição para ter uma qualidade e um bom desempenho, mas às vezes eu preciso usar o mesmo conteúdo, mas de formas diferentes. Por exemplo, esse aparelho poderia servir, se eu quisesse falar de ritmo, eu poderia não ter de trabalhar só a percussão e ai trabalharia com essa ferramenta e trabalharia o violão e trabalharia com outros recursos, mas falando do mesmo assunto".

Em relação aos canais de colaboração percebidos na escola GEO, a escola Operário Vicente Mariano teve uma configuração diferente. O professor-pesquisador percebeu nitidamente a colaboração entre os estudantes que usavam o artefato, mas os estudantes que observavam os seus colegas que operavam o artefato não interagiam entre si e também não interagiam com os estudantes que usavam o artefato.

\section{Conclusão}

Afinal, o artefato mostrou-se aceitável pelos alunos, professores e escola? Não é fácil dar uma resposta inequívoca do tipo "sim" ou "não" para esta questão de pesquisa. Alunos, professores e pesquisadores consideraram que $o$ artefato: funciona adequadamente (Expectativa de Performance), é fácil de usar (Expectativa de Esforço), é prazeroso de usar (Motivação Hedônica), e os alunos têm vontade de ter outras aulas com o uso do artefato (Intenção de Uso). Assim, temos indícios para concluir que $\mathrm{o}$ artefato tem potencial para ser aceito pelos alunos. Por outro lado, reconhecemos que o artefato é apenas um protótipo, e não um produto já acabado que possa ser comprado nas prateleiras de alguma loja acompanhado de manual e suporte técnico. Nestas condições, enquanto ainda um protótipo, os professores das escolas mostramse hesitantes em adotá-lo por sua instalação parecer complexa e demandar muito tempo (Condições Facilitadoras). Adicionalmente, apesar do custo do protótipo ser relativamente baixo em comparação com muitos instrumentos musicais tradicionais (Custo), não temos certeza se este custo será mais baixo ou mais alto se vier a ser produzido em larga escala. Por estes aspectos, não é possível afirmar se o artefato, se vier a se tornar um produto, terá aceitação por parte dos professores e da escola. Dependerá de dados que não foram possíveis de serem levantados nesta pesquisa.

Sobre as conjecturas teóricas, todas mostraram-se válidas, os resultados obtidos no estudo de caso corroboram com a validade do quadro teórico ao menos dentro dos limites deste trabalho. Os mais conservadores devem questionar: o letramento no discurso musical também é promovido com base no Comportamentalismo, sem fazer uso de colaboração ou do corpo. Não foi objetivo nesta pesquisa mostrar que o letramento é melhor ou pior entre as diferentes abordagens; nosso objetivo aqui foi somente mostrar que também é possível promover o letramento com o uso do artefato proposto na perspectiva teórica conjecturada. Os mais conservadores também devem questionar que aprender um instrumento musical tradicional faz parte do letramento no discurso musical. Concordamos com esta afirmação, mas consideramos que o letramento no discurso musical não requer a aquisição da técnica mecânica de se tocar um instrumento tradicional, e, como mostrado nesta pesquisa, o artefato possibilita explorar os elementos do discurso musical mais facilmente do que com o uso de instrumentos tradicionais, o que nos pareceu ser adequado principalmente nos anos iniciais de formação no discurso musical.

Consideramos que a presente pesquisa apresenta contribuições técnicas, educacionais, teóricas e metodológicas:

- Técnicas: os tapetes musicais inteligentes projetados nesta pesquisa mostrou-se um artefato tecnológico adequado para ser utilizado em sala de aula no apoio a aulas de música;

- Educacionais: as atividades aqui propostas com o uso do artefato apresentaram-se adequadas para possibilitar aos estudantes a exploração ativa e autoral do discurso musical;

- Teóricas: o uso do artefato em contextos reais cor- 
roborou com as noções de que o letramento no discurso musical é apoiado pela diminuição das barreiras técnicas na produção do som, pelo uso do corpo e pela colaboração;

- Metodológicas: o método Design Science Research, aqui usado para estruturar a presente pesquisa, mostrouse adequado por conjugar o projeto de design de um artefato tecnológico na área de Informática na Educação para a solução de um problema focalizando o desenvolvimento de conhecimento científico.

Ficamos tão bem impressionados com o projeto desenvolvido e pesquisado nesta dissertação que tentaremos patentear os "Tapetes Musicais Inteligentes". Em ações futuras, pretendemos estabelecer parcerias comerciais para elaborarmos um conceito de produto e viabilizar a produção e distribuição do produto derivado desta pesquisa. Adicionalmente, planeja-se novos estudos que comparem instrumentos musicais tradicionais com os Tapetes Inteligentes.

\section{Referências}

[1] P. S. Campbell, Musician and Teacher. New York: W.W. Norton and Company, 2008.

[2] V. Candau, M. N. T. Zenaide, (org) Oficinas Aprendendo e Ensinando Direitos Humanos. João Pessoa: J. B. Editora. 1999.

[3] A. Castro, C. Menezes. Aprendizagem Colaborativa com Suporte Computacional. Capítulo 9. Sistemas Colaborativos. M. Pimentel, H. Fuks. (Organizadores) Ed. Elsevier/Campus, Rio de Janeiro. 2011.

[4] Censo da educação básica: 2013 - resumo técnico. - Brasília: Instituto Nacional de Estudos e Pesquisas Educacionais Anísio Teixeira, 2014.

[5] B. Cope, M. Kalantzis. Ubiquitous Learning. 2009.

[6] E. J. Dalcroze. Rhythm music and Education.G.P.Putnam's Sons New York. 1921.

[7] A. Dresch, et al. Design science research: método de pesquisa para avanço da ciência e tecnologia. Porto Alegre: Bookman, 2014. 204p.

[8] D. Filippo, M. Pimentel, J. Wainer. Metodologia científica para a Pesquisa em Sistemas Colaborativos. Capítulo 23. Sistemas Colaborativos. M. Pimentel, H. Fuks, (Organizadores) Ed. Elsevier/Campus, Rio de Janeiro. 2011. Disponível em https:/www.dropbox.com/sh/ftcq79y2aqq16u4/

\section{sFxQwE8iO}

[9] D. Filippo, J.Viterbo, M. Endler, H. Fuks. Mobilidade e ubiquidade para colaboração. Capítulo 18. Sistemas Colaborativos. M. Pimentel, H. Fuks, (Organizadores) Ed. Elsevier/Campus, Rio de Janeiro. 2011.

[10] J. Frazee, K. Kreuter. Discovering Orff: A Curriculum for Music Teachers (Schott) Paperback - January 1997.

[11] A. Hevner, S. March, J. Park, S. Ram. Design Science in Information Systems Research. MIS Quarterly (28:1), pp. 75-105. 2004.

[12] A. Hevner, S. Chatterjee. Design Research in Information Systems. Ed. Springer New York. 2010 .

[13] Joylabz (2016) http://joylabz.com

[14] Lei Federal 11.796/ 2008, de 18 de agosto de 2008. Diário Oficial da República Federativa do Brasil, Brasília, DF, n. 159, p. 1, 19 ago. 2008.

[15] Makey Makey http://www.makeymakey.com/

[16] A. M. Nicolaci-da-Costa, "O Campo da Pesquisa Qualitativa e o Método de Explicitação do Discurso Subjacente ( MEDS )". Psicologia: Reflexão e Crítica, v. 20, n. 1, p. 65-73. de Explicitação do Discurso Subjacente ( MEDS )". Psicologia: Reflexão e Crítica, v.20, n. 1, p. 65-73. 2005.

[17] OLPC (2016) http://one.laptop.org

[18] PARÂMETROS CURRICULARES NACIONAIS. (PCNs) 2. Arte : Ensino de quinta a oitava séries. Secretaria de Educação Fundamental. - Brasília : MEC / SEF.1998.

[19] J. Piaget, (2013). A psicologia da inteligência. Editora Vozes - Rio de Janeiro.

[20] Z. Rhen, R. MEHRA, J. COPOSKY, M. Lin. Tabletop ensemble:touch-enabled virtual percussion instruments.I3D Proceedings of the ACM SIGGRAPH Symposium on Interactive 3D Graphics and Games. 2012.

[21] W. Richardson. Why school? : How Education Must Change When Learning and information Are Everywhere TED Conferences (September 10, 2012).

[22] D. Rosen, E. Schmidt, Y. KIM. Utilizing music technology as a model for creativity development in K-12 education. C\&C 13: Proceedings of the $9^{\text {th }}$ ACM Conference on Creativity an 


\section{Cognition. (2013).}

[23] T. Santos, D. Filippo, M. Pimentel. Computação Ubíqua para apoiar a educação musical: explorações com o Makey Makey. XXI Workshop de Informática na Escola (WIE) 2015.

[24] T. Santos. Computação Ubíqua para apoiar a Educação Musical: Explorações com Tapetes Musicais Inteligentes. 212 pgs. Dissertação de mestrado - Programa de Pós Graduação em Informática (PPGI), Universidade Federal do Estado do Rio de Janeiro (UNIRIO), Rio de Janeiro. 2015.

[25] E. Shahar. SoundStrand: Composing with a Tangible Interface. NIME'12, May 21-23, University of Michigan, Ann Arbor. 2012

[26] H. A. Simon. The Sciences of the Artificial (1st ed.), Cambridge, MA: MIT Press. (1969).

[27] Soundplant (2014) http://soundplant.org/

[28] K. Swanwick, J. Tillman, 1986 June. The Sequence of Music Development: a study of children's composition. British Journal of Music Education, 3(3): 305-339, Nov, 1986.

[29] UCA (2016)http://www.uca.gov.br/institucional/

[30] V. Venkatesh, J. Y. L. Thong, X. Xu. "Consumer acceptance and use of information technology: extending the unified theory of acceptance and use of technology". MIS Quarterly Vol. 36 No. 1 pp. 157-178/March 2012.

[31] V. Venkatesh, M. G. Morris, G. B. Davis, F. D. Davis. "User Acceptance of Information Tech- nology: Toward a Unified View," MIS Quarterly (27:3), p. 425-478. 2003.

[32] L. Vygotsky. (1989) Pensamento e linguagem. São Paulo: Martins Fontes, 1989.

[33] G. Volpe, G. Varni, B. Mazzarino, A. Addessi. BeSound: Embodied Reflexion for Music Education in Childhood. IDC 2012 SHORT PAPERS 12th-15th June, Bremen, Germany

[34] M. Weiser. The computer for the twenty-first century. Scientific American, 65(3):94104.1991.

[35] R. Yin. Estudo de Caso Planejamento e Métodos, Bookman. 2015.

[36] C. Zhang, L. Shen, D. Wang, F. Tian, H. Wang. 2011) CoolMag: A Tangible Interaction Tool to Customize Instruments for Children in Music Education.UbiComp'11 / Beijing, China

[37] Y. Zhou, G. Percival, X. Wang, Y. Wang, S. Zhao. MOGCLASS: Evaluation of a Collaborative System of Mobile Devices for Classroom Music Education of Young Children School of Computing (SoC), National University of Singapore- CHI-2011. 